Chapter 19

\title{
Carbon Nanotube-Enzyme Biohybrids in a Green Hydrogen Economy
}

\author{
Anne De Poulpiquet, Alexandre Ciaccafava, \\ Saïda Benomar, Marie-Thérèse Giudici-Orticoni and \\ Elisabeth Lojou
}

Additional information is available at the end of the chapter

http://dx.doi.org/10.5772/51782

\section{Introduction}

Alternative energy pathways to replace depleting oil reserves and to limit the effects of global warming by reducing the atmospheric emissions of carbon dioxide are nowadays required. Dihydrogen appears as an attractive candidate because it represents the highest energy output relative to the molecular weight (120 MJ kg-1 against $50 \mathrm{MJ} \mathrm{kg}^{-1}$ for natural gas), and because its combustion delivers only water and heat. Whereas the main renewable sources of energy available in nature (solar, wind, geothermal...) need to be transformed, dihydrogen is able to transport and store energy. Dihydrogen can be produced from renewable energies, indirectly from photosynthesis via biomass transformation, or directly by bacteria. It can be converted into electricity using fuel cell technology. From all these properties and because it does not compete with food and water resources, dihydrogen has been defined as third generation biofuel. It thus emerges as a new fully friendly environmental energy vector. The use of dihydrogen as an energy carrier is not a new idea. Let us simply remember that Jules Verne, a famous French visionary novelist, wrote early in 1874: "I believe that $\mathrm{O}_{2}$ and $\mathrm{H}_{2}$ will be in the future our energy and heat sources" [1]. His prediction simply relied on the discovery a few years before of the fuel cell concept by C. Schönbein, then W. Groove, who demonstrated that when stopping water electrolysis, a current flow occurred in the reverse way [2]. However in order to implement the dihydrogen economy and replace fossil fuels, there are significant technical challenges that need to be overcome in each of the following domains: 
1. dihydrogen production and generation,

2. dihydrogen storage and transportation,

3. dihydrogen conversion to electrical energy.

As opposed to widespread opinions, natural dihydrogen sources exist alone on the earth's surface. Local and continuous emanations of dihydrogen can be observed in cratonic zones, ophiolitic rocks or oceanic ridges [3]. Dihydrogen is effectively produced in the upper mantle of the earth through natural oxidation of iron (II)-rich minerals, like ferromagnesians, by water of the hydrosphere. The ferrous iron is oxidized in ferric iron and water is concurrently reduced in dihydrogen, as given by following equation: $2 \mathrm{Fe}^{2+}$ (mineral) $+2 \mathrm{H}^{+}$(water) $\rightarrow 2$ $\mathrm{Fe}^{3+}$ (mineral) $+\mathrm{H}_{2}$. The same reaction can occur with other ions like $\mathrm{Mn}^{2+}$. Exploitation of these sources remains however difficult so far as dihydrogen does not accumulate on the earth subsurface, especially for two reasons. First because as a powerful energy source dihydrogen is quickly consumed (biologically or abiotically), and second because as the lightest and most mobile gas it is not much retained by Earth's attraction and escapes in the atmosphere.

Combined with water and hydrocarbons dihydrogen is nevertheless the most abundant element on earth. Green means to ecologically convert $\mathrm{H}$ containers into dihydrogen still remain however challenging. The energetic volume density of dihydrogen is low (10.8 $\mathrm{MJ} \mathrm{m}^{-3}$ against $40 \mathrm{MJ} \mathrm{m}^{-3}$ for natural gas) so that storage and transportation appear as bottlenecks for large scale development in transportation for example. Conversion of dihydrogen to electricity in fuel cells presents high electrical efficiency (more than $50 \%$ against less than $30 \%$ for gas engines), but requires the use of catalysts both for $\mathrm{H}_{2}$ oxidation and $\mathrm{O}_{2}$ reduction. These are mainly based on platinum catalysts, which are highly expensive, weakly available on earth, and non biodegradable. Extensive researches thus aim to decrease the amount of platinum catalysts in fuel cells. Following the discovery of carbon nanotubes (CNTs) [4, 5], their large scale availability opened a new avenue in these three domains. Due to their intrinsic properties, such as high stability, high electrical and thermal conductivities [6] and high developed surface areas, carbon nanotubes constitute attractive materials, able to enhance the credibility of an hydrogen economy.

Besides, platinum catalysts are inhibited by very low amount of $\mathrm{CO}$ and $\mathrm{S}(0.1 \%$ of $\mathrm{CO}$ is sufficient to decrease one hundred fold the catalytic activity of Pt in ten minutes!), thus requiring strong steps of $\mathrm{H}_{2}$ purification [7]. They are not specific to either $\mathrm{O}_{2}$ or $\mathrm{H}_{2}$ catalysis, thus requiring the use of a membrane to separate the anodic and cathodic compartments. Nafion ${ }^{\circledR}$ perfluoronated membrane is currently the only really performing polymer [8], increasing its cost. Replacement of platinum-based catalysts is thus highly needed. In that way, a new concept appeared less than five years ago, when looking at the pathways microorganisms use for the production of ATP, their own energetic source [9, 10]. As an example, the hyperthermophilic, microaerophilic bacterium Aquifex aeolicus, couples $\mathrm{H}_{2}$ oxidation to $\mathrm{O}_{2}$ reduction via a membrane quinone pool (Figure 1). The redox coupling generates a proton gradient through the cell membrane for ATP synthesis. Clearly, this pathway can be considered as an "in vivo biofuel cell". The question rises if we could take benefit of bacterial energetic pathways for our own energetic needs. The idea thus emerged that microorgan- 
isms or enzymes could be used instead of chemical catalysts for the development of efficient electricity producing devices. These innovative batteries called biofuel cells rely on enzymes highly specific for various fuels and oxidants [11]. A mandatory condition is that these enzymes have to be immobilized onto electrodes. One of the most common biofuel cell uses glucose oxidase and laccase, two enzymes specific for glucose oxidation and oxygen reduction, respectively. A few years ago, a new concept of biofuel cells appeared based on enzymes specific of dihydrogen oxidation. This biohydrogen economy relies on the opportunity to use low-cost materials for efficient conversion of solar energy to dihydrogen and of dihydrogen to electricity. Many microorganisms biosynthesize hydrogenase, the metalloenzyme that catalyzes the dihydrogen conversion. At least two modes of application of dihydrogen-metabolizing protein catalysts are nowadays considered within dihydrogen as a future energy carrier. Hydrogenases may be used as catalysts in dihydrogen production by coupling oxygenic photosynthesis to biological dihydrogen production [12]. Hydrogenases can also be used directly as anode catalysts in biofuel cells instead of chemical catalysts [13]. The improved knowledge of hydrogenase structure and of catalytic mechanisms allows nowadays to design the development of biofuel cells functioning as Proton Exchange Membrane (PEM) fuel cells.
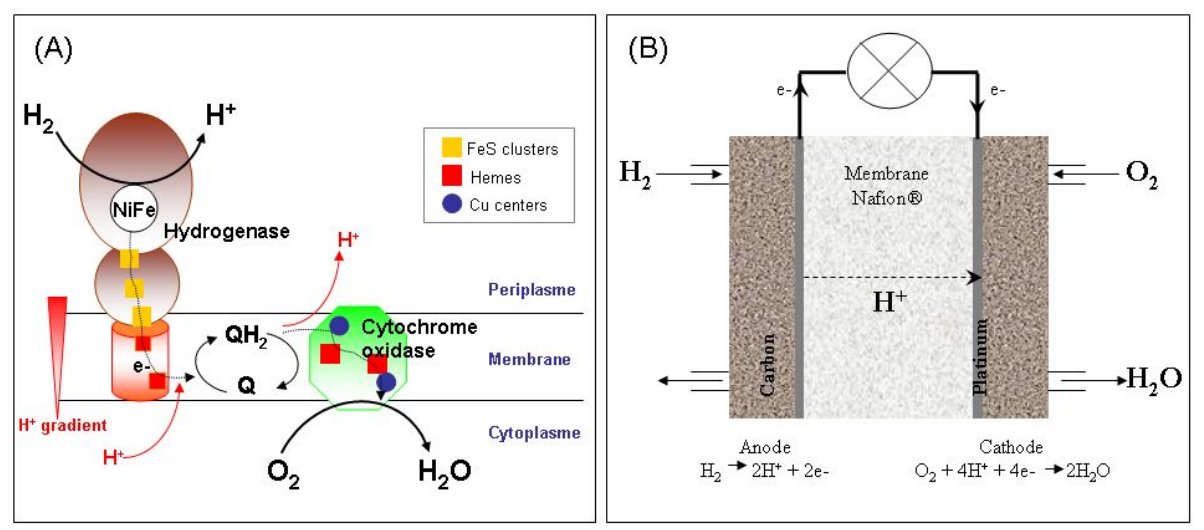

Figure 1. A) Energetic metabolism of the bacterium Aquifex aeolicus: $\mathrm{H}_{2}$ oxidation in the periplasm is coupled to $\mathrm{O}_{2}$ reduction in the cytoplasm via a membrane quinone pool to generate a trans-membrane proton gradient for ATP synthesis; (B) General view of a chemical PEM fuel cell.

For all these innovative concepts, one of the key points is the increase in power density, thus in the current density furnished by a redox couple displaying a large as possible potential difference. Apart from the improvement in enzyme stability, the increase in the current densities supposes an optimization of both the interfacial electron transfer rate and the amount of connected enzymes at the electrode. Carbon nanotubes which develop large surface areas and can be functionalized constitute an attractive platform for such enzyme immobilization. CNTs are described as graphene sheets rolled into tubes. They exist under various structural configurations (single-walled (SWCNTs), multi-walled (MWCNTs)) differing in electrical proper- 
ties, thus tuning the platform properties for enzyme immobilization. The end of the tubes is capped by a fullerene-type hemisphere that yields selective functionalization of the CNTs [14].

With the objective of dihydrogen as a future green energy vector, this review focuses on the last developments in the fuel -and more especially biofuel- cell field thanks to the advantageous use of carbon nanotubes. In a first part, carbon nanotubes for $\mathrm{H}_{2}$ storage enhancement are discussed. Then fuel cells in which carbon nanotubes help to decrease the amount of high cost noble metal catalysts are described. Green $\mathrm{H}_{2}$ economy is then emphasized considering the key role of hydrogenase, the enzyme responsible for dihydrogen conversion. This requires the functional immobilization of the biocatalysts onto electrodes. The use of carbon nanotubes in this immobilization step is underlined, including the modes of carbon nanotube functionalization and enzyme or microbes grafting. Then the advantages of developing biofuel cells in which chemical catalysts are replaced by enzymes or microbes are described. A short review of the sugar $/ \mathrm{O}_{2}$ biofuel cells, the most widely investigated biofuel cell, is given with a particular attention on the devices based on carbon nanotube-modified bioelectrodes. The last developments based on carbon nanotube networks for hydrogenase immobilization, or mimicking synthetic complex immobilization, in view of efficient dihydrogen catalytic oxidation are finally described in order to allow the design of a future $\mathrm{H}_{2} / \mathrm{O}_{2}$ biofuel cell.

\section{Carbon nanotubes: an attractive carbon material}

The discovery of carbon nanotubes (CNTs) has induced breakthroughs in many scientific domains, including $\mathrm{H}_{2}$ economy, biosensors, bioelectrochemistry...This is due to their remarkable properties, such as good electronic, mechanical and thermal properties. Their nanometric size compares with that of proteins and enzymes, offering the possibility of electrical connection. Their large developed surface area allows the development of devices in smaller volumes. SWCNTs are sp2 hybridized carbon in a hexagonal honeycomb structure that is rolled into hollow tube morphology [15]. MWCNTs are multiple concentric tubes encircling each other [5]. Depending on the chirality, CNTs can be metallic or semiconducting. The distinction between metallic and semiconducting is very important for application, but the physical separation of allotropes is one of the most difficult challenges to overcome. In MWCNTs, a single metallic layer results in the entire nanotubes metallic behavior. Most often mixtures of these two forms are present in CNTs preparation. More information on the physical and electronic structures can be found in many published reviews [16]. CNTs are produced by various methods such as arc discharge, laser ablation, and chemical vapor deposition (CVD). Commercially CNTs are generally produced by CVD during the pyrolysis of hydrocarbon gases at high temperature. The control of synthesis parameters (reagent gas, $\mathrm{T}$ $\circ$, metal catalysts) allows for the control of CNT properties. Metal impurities may remain in the CNTs sample, thus requiring purification steps. CNTs may be treated to functionalize the surface. 


\section{Carbon nanotubes for safe and efficient $\mathrm{H}_{2}$ storage}

The use of $\mathrm{H}_{2}$ in fuel cells to generate electricity has been proved early in the middle of the nineteenth century. Surprisingly this discovery by C. Schönbein in 1839 of current generation by use of $\mathrm{H}_{2}$ and $\mathrm{O}_{2}$ in sulphuric acid was applied by NASA only late in 1960. Despite intensive studies over the last two decades, fuel cells still suffer from high cost and low durability. The first difficulty responsible for this slow large scale development lies on dihydrogen storage and transportation, both regarded as bottlenecks considering dihydrogen specific volumic density as a gas. For convenience the gas must be intensely pressurized to several hundred atmospheres and stored in a pressure vessel. The ways to store dihydrogen with minimum hazard are under liquid state under cryogenic temperatures (at a temperature of $-253{ }^{\circ} \mathrm{C}$ ), or more efficiently in a solid state. Storage of dihydrogen in hydride form uses an alloy that can absorb and hold large amounts of dihydrogen by bonding with hydrogen and forming hydrides. A dihydrogen storage alloy is capable of absorbing and releasing dihydrogen without compromising its own structure, according to the reaction: $\mathrm{M}+$ $\mathrm{H}_{2} \leftrightarrow \mathrm{MH}_{2}$, where $\mathrm{M}$ represents the metal and $\mathrm{H}$, hydrogen. Qualities that make these alloys useful include their ability to absorb and release large amounts of dihydrogen gas many times without deteriorating, and their selectivity toward dihydrogen only. In addition, their absorption and release rates can be controlled by adjusting temperature or pressure. The dihydrogen storage alloys in common use occurs in four different forms: $\mathrm{AB}_{5}$ (e.g., $\mathrm{LaNi}_{5}$ ), $\mathrm{AB}$ (e.g., FeTi), $\mathrm{A}_{2} \mathrm{~B}$ (e.g., $\mathrm{Mg}_{2} \mathrm{Ni}$ ) and $\mathrm{AB}_{2}$ (e.g., $\mathrm{ZrV}_{2}$ ). Metal hydrides, such as $\mathrm{MgH}_{2}$, $\mathrm{Mg}_{2} \mathrm{NiH}_{4}$ or $\mathrm{LiBH}_{4}$, constitute secure reserves of dihydrogen [17-19]. Dihydrogen is released from $\mathrm{MH}_{2}$ upon increase in temperature and/or decrease in pressure.

\begin{tabular}{ccccccc}
\hline Material & $\begin{array}{c}\mathbf{H}_{2} \text { gas, } \\
\mathbf{2 0 0} \text { bar }\end{array}$ & $\begin{array}{c}\mathbf{H}_{2} \text { liquid, } \\
\mathbf{- 2 5 3 \mathbf { C }}\end{array}$ & $\mathbf{M g H}_{2}$ & $\mathbf{M g}_{2} \mathrm{NiH}_{4}$ & $\mathrm{FeTiH}_{2}$ & $\mathrm{LaNi}_{5} \mathrm{H}_{6}$ \\
\hline $\begin{array}{c}\text { H-atom per cm } \\
\left(\times 10^{22}\right)\end{array}$ & 0.99 & 4.2 & 6.5 & 5.9 & 6.0 & 5.5 \\
\hline
\end{tabular}

Table 1. H density as a function of storage method.

Much progress has been made during the last years in that domain, including the highlight of the advantages offered by using CNTs. An efficient approach appears to be the formulation of new carbon/transition metal catalyst composites of specific composition and molecular structure, which can greatly stimulate and improve the chemical reactions involving dihydrogen relocation in alkali-metal aluminium materials. Absorption kinetics and dihydrogen storage capacity were shown to be enhanced by mixing $\mathrm{MH}_{2}$ with SWCNTs as a result of an increase in interfacial area, decrease in $\mathrm{MH}_{2}$ particle agglomeration and nanoplatform for efficient $\mathrm{H}_{2}$ diffusion [20, 21]. The hydriding and dehydriding kinetics of SWCNT/catalyzed sodium aluminium composite were found to be much better than those of the material ground without carbon additives. Temperature of $\mathrm{H}_{2}$ desorption was lowered [22]. The presence of carbon creates new dihydrogen transition sites and the high dihydrogen diffusivity of the nanotubes facilitates hydrogen atom transition. Faster ther- 
mal energy transfer through the nanotubes may also help reduce hydriding and dehydriding times.

Dihydrogen can be stored through physisorption on CNTs, based on Van der Waals interaction. Based on the surface area of a single graphene sheet, the maximum value for the storage of dihydrogen capacity is around $3 \mathrm{wt} \%$. Dihydrogen can also be stored through chemisorption in CNTs matrix. If the $\pi$-bonding between carbon atoms were fully utilized, every carbon atom could be a site for chemisorption of one hydrogen atom. Dillon et al. first reported in 1997 dihydrogen storage in SWCNT networks [23]. Both SWCNTs and MWCNTs store dihydrogen in microscopic pores on the tubes [24, 25]. Similar to metal hydrides in their mechanism for storing and releasing dihydrogen, the carbon nanotubes hold the potential to store a significant volume of dihydrogen. The storage capacity is dependent on many parameters of the CNTs, including their structure, structure defects, pretreatment, purification, geometry (surface area, tube diameter, length), arrangement of tubes in bundles, storage pressure, temperature,...Dihydrogen uptake varies linearly with tube diameter, because the uptake is proportional to the surface area, i.e. the number of carbon atoms. The adsorption sites exist inside and outside the tube, between tubes in bundles, between the shells in MWCNTs. For dihydrogen storage into the tube dihydrogen must pass through the CNT wall or the tube must be opened. Hydrogen forms stable C-H bonds on SWCNT surface at room temperature that can dissociate above $200^{\circ} \mathrm{C}$. According to SWCNT diameter $100 \%$ hydrogenation can be obtained, thus more than 7 wt \% dihydrogen storage capacity, which is above the target fixed by the US Department of Energy's Office of Energy Efficiency and Renewable Energy [26].

\section{Carbon nanotubes for a decrease in the amount of noble metal catalysts in fuel cells}

Among the different types of fuel cells, PEM fuel cell operates at low temperatures around $100^{\circ} \mathrm{C}$. For small portable application requiring less than $10 \mathrm{~kW}$, they are more suitable than higher powering solid oxide fuel cells (functioning at $700^{\circ} \mathrm{C}$ ) due to the possible use of usual materials for electronic connectors (mainly based on carbon) and membrane. However the necessary use of platinum-based catalysts on electronic connectors to accelerate the rate of dihydrogen oxidation and oxygen reduction is a real brake towards the fuel cell development. Platinum is scarce enough on earth to be a limiting factor in case of large scale development of fuel cells. Consequently platinum currently accounts for $25 \%$ in the total cost of a fuel cell. Over the past five years, the price of platinum has ranged from just below $\$ 800$ to more than $\$ 2,200$ an ounce. Carbon black particles offer a high surface area support, able to decrease the amount of platinum particles. But they suffer from mass transfer limitations and strong carbon corrosion.

Among the low-cost alternatives to platinum, carbon appears to be the most promising. Due to their nano-structure and unique chemical and physical properties, CNTs have appeared 
as ideal supporting materials to improve both catalytic activity and electrode stability. The enhancement of fuel cell performances by using CNT/Pt or Pt-alloy catalysts may arise from:

i. higher dispersion of Pt nanoparticles,

ii. increased electron transfer rates,

iii. porous structure of CNT layers.

Various CNT-Pt composites were used to reduce the platinum amount while preserving high catalytic activity in PEM fuel cells. Platinum nanodots sputter-deposited on a CNTgrown carbon paper [27], or deposited on functionalized MWCNTs [28] exhibited great improvement in cell performance compared to platinum on carbon black. This was primarily attributed to high porosity and high surface area developed by the CNT layer. Compared to a commercial Pt/carbon black catalyst, Pt/SWCNT films cast on a rotating disk electrode was shown to exhibit a lower onset potential and a higher electron-transfer rate constant for oxygen reduction. Improved stability of the SWCNT support was also confirmed from the minimal change in the oxygen reduction current during repeated cycling over a period of $36 \mathrm{~h}$ [29]. Platinum particles deposited on MWCNT encapsulated in micellar surfactant were also explored as efficient catalysts for fuel cells [30,31]. An in situ synthetic method was reported for preparing and decorating metal nanoparticles at sidewalls of sodium dodecyl sulfate micelle functionalized SWCNTs/MWCNTs. Accelerated durability evaluation was carried out by conducting 1500 potential cycles between 0.1 and $1.2 \mathrm{~V}$ at $80^{\circ} \mathrm{C}$. These nanocomposites were demonstrated to yield a high fuel cell performance with enhanced durability. The membrane electrode assembly with Pt/MWCNTs showed superior performance stability with a power density degradation of only $30 \%$ compared to commercial $\mathrm{Pt} / \mathrm{C}(70 \%)$ after potential cycles. Identically electrocatalytically active platinum nanoparticles on CNTs with enhanced nucleation and stability have been demonstrated through introduction of electronconducting polyaniline (PANI) [32]. A bridge between the Pt nanoparticles and MWCNTs walls was demonstrated with the presence of platinum nitride bonding and $\pi-\pi$ bonding. The synthesized PANI was found to wrap around the CNT as a result of $\pi-\pi$ bonding, and highly dispersed Pt nanoparticles were loaded onto the CNT with narrowly distributed particle sizes ranging from 2.0 to $4.0 \mathrm{~nm}$. The Pt-PANI/CNT catalysts were electroactive and exhibited excellent electrochemical stability, therefore constitute promising potential applications in proton exchange membrane fuel cells. Strong evidence thus emerges that $\mathrm{CNTs} / \mathrm{Pt}$ composites are efficient as catalysts for fuel cells. Although platinum content has been dramatically decreased, industrials consider that further optimization is mandatory for a large scale fuel cell production. In addition Nafion ${ }^{\circledR}$ membrane between the cathodic and anodic compartment delays the large scale application of fuel cells, due to cost and problem of mass transfer. Breakthrough research towards these two bottlenecks could surely enforce a hydrogen economy. 


\section{Towards a green $\mathrm{H}_{2}$ economy: carbon nanotubes for enzyme and microbe immobilization}

Replacement of chemical catalysts is thus nowadays highly needed in view of the development of a green energy economy. Microorganisms contain many biocatalysts, namely enzymes, which are highly efficient and specific towards various substrate conversions. Given they are produced in large enough quantities, these enzymes could be used as catalysts in biotechnological devices. A mandatory condition to develop heterogeneous catalysis is to succeed in the functional immobilization and in the stabilization of the enzymes on solid supports. The redox active site of enzymes is indeed buried inside the protein moiety so that the enzymatic property can be maintained under environmental stresses. Specific channels are often involved to allow the substrate to reach the active site. Complex but highly organized electron transfer chains occur for energetic metabolism. Electron transfer between two physiological partners associated with transformation of the substrate involves specific recognition site. The game for a bioelectrochemist that aims to get the highest electron transfer rate for heterogeneous catalysis is to reproduce at the electrode interface the physiological electron transfer recognition process. Given the usual size of an enzyme (5-10 nm), electron transfer cannot occur via electron tunneling from the active site to the surface of the enzyme. In some enzymes, electron relays, one being located at the protein surface, act as a conductive line for electron shuttling. If the electrode interface is built so that it fits the surface electron relay environment, one can expect to favor a direct electrical connection of the enzyme onto the electrode. In case of direct electron transfer failure, an artificial redox mediator that acts as a fast redox system and shuttles electrons between the enzyme and the electrode can be used (Figure 2) [13, 33].

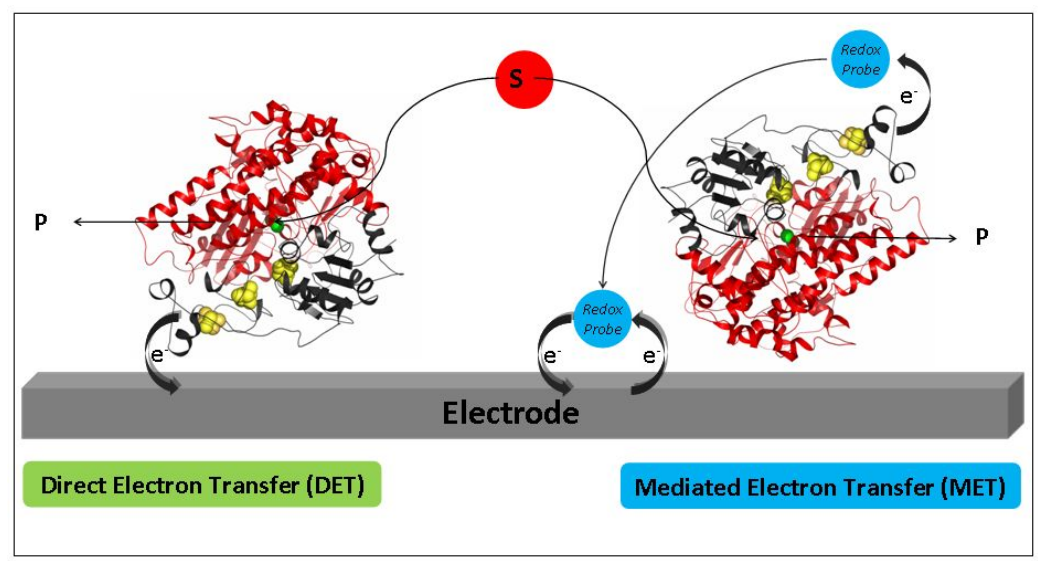

Figure 2. Interfacial electron transfer between an enzyme and an electrode can be achieved by direct (left) or mediated (right) electron transfer process. 
Direct electron transfer process is preferred to mediated one, because it is not limited by the affinity between the enzyme and the redox mediator, and because it avoids the co-immobilization of enzyme and mediator. It is furthermore expected to yield the highest power density because enzymes, as biocatalysts, transform their substrate into products with very low overvoltages. However it requires the knowledge of the protein structure and the construction of a tuned electrochemical interface that fits the electron transfer site.

There are many strategies for efficient enzyme immobilization onto electrochemical interfaces, including simple physical adsorption, covalent attachment, cross-linking or entrapment in polymers. The objectives are to optimize the immobilization procedure so that the efficiency of the enzyme and its stability are preserved. Moreover, due to the size of enzymes compared to chemical catalysts, large surface area interfaces baring many anchorage sites are required to obtain high catalytic currents.

To reach these goals, 3D structures are preferred, and CNT-based electrodes are very popular, both SWCNTs and MWCNTs. CNTs can be directly grown onto electrode surface, or adsorbed on it, or imbedded in polymer coating. In most cases, higher activity was reported for enzymes physically adsorbed onto CNTs [34]. Hydrophobic interactions between the enzyme and the CNT walls and $\pi-\pi$ interactions between side walls of CNTs and aromatic rings of the enzyme are thought to be the driving force for direct adsorption of enzymes on CNTs [35]. Electrostatic interaction between the defect sites of CNTs and protonated amino residues of the enzyme plays also a role in the adsorption process [35]. CNTs are quite easily functionalized, allowing covalent, thus stable specific attachment of enzymes. The oxidation in strong acidic solutions at high temperature was demonstrated to remove the end caps and shorten the lengths of the CNTs. The length of the CNTs was shown to be a function of the oxidation duration [36]. Acid treatment also adds oxide groups, primarily carboxylic acids, to the tube ends and defect sites [37]. The control of reactants and/or oxidation conditions may control the locations and density of the functional groups on the CNTs, which can be used to control the location and density of the attached enzymes [37]. Covalent immobilization is induced by carbodiimide reaction between the free amine groups on the enzyme surface and carboxylic groups generated by side wall oxidation of CNTs.

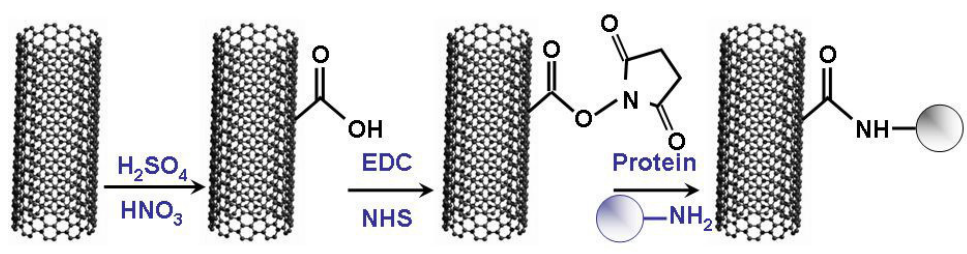

Further chemical reactions can be performed at the oxide groups generated on the oxidized CNTs to functionalize with groups such as amides, thiols, etc...From an electrochemical point of view, the side walls of CNTs were suggested to behave as basal plane of pyrolytic graphite, while their open ends resemble the edge planes [38, 39]. But recent work has demonstrated that the side wall may be responsible for electrochemical activity [40]. It has been 
furthermore suggested that the uncovered surface of CNTs promotes the accessibility of the substrate to the enzyme [41]. It is also interesting to note that the open spaces between CNTs are accessible to large species such as entire bacteria [42], opening the way for the development of fuel cells using whole microorganisms instead of purified enzymes. The cost and complexity of CNT manufacturing seem to be still clogging issues in that field.

Abundant literature exists on the ways CNTs are architectured for efficient enzyme immobilization, including those specific for development of enzymatic fuel cells. Enzymes and proteins as various as glucose oxidase and dehydrogenase, tyrosinase, laccase and bilirubin oxidase, peroxidase, haemoglobin and myoglobin, i.e. flavin, copper or heme containing active sites, have been studied. Whereas direct electron transfer between protein or enzyme and an electrochemical interface has been for long time supposed to be restricted to small proteins $(<15 \mathrm{kDa})$ possessing active sites exposed to the surface (it is the case for many cytochromes as example [43]), the use of CNT-modified electrodes has greatly enhanced the number and kinds of enzymes able to be directly connected to an electrode. Enzymes as large as one hundred $\mathrm{kDa}$, with many cofactors are now considered for direct electron transfer. Consequently, recent works during the last years focus and report on direct communication between enzymes and electrode interface through CNT network. The induced porosity of the film depends on the type of CNTs used. But generally the nanometric size of the CNTs compared to the size of enzymes favors a direct electronic connection of the enzyme whatever its orientation [44]. The physical properties of CNTs, including high electrical conductivity, explain why CNT layers can be built up on electrodes most often yielding high rate direct electron transfer for enzymatic product transformation. Many researches report on the increase in electroactive surface area by use of CNT coatings that contribute to an increase in the direct electron transfer process [45-52]. CNTs are usually deposited on electrodes as thick films. Alternatively, layer-by-layer (LBL) process induces a quite stable protein film with nice electrocatalytic properties [53-55]. LBL is based on electrostatic interaction between oppositely charged monolayers in an alternating assembling. Although CNTs greatly amplify the current response, layer-by-layer architecture suffers from weak stability of the build-up and decrease in electron transfer for the upper layers. Besides vertically aligned CNTs were suggested to act as molecular wires that ensure the electrical communication between enzyme and electrode [56-58]. The carboxylic functions induced by acidic treatment of CNTs can be used for further chemical modifications. Amine- [59-61], thionin- [62, 63], diazonium salts $[64,65]$, pyrene $[66,67]$ (Figure 3) or other $\pi-\pi$ stacking interactions [68] were used to functionalize CNTs. These modifications were demonstrated to be efficient platforms for enzyme immobilization.

Mixing CNTs with surfactant [69-71] was claimed to assist in the dispersion of CNTs while avoiding oxidative functionalization which may disrupt their $\pi$-network. Polymer modified CNTs $[72,73]$ and sol-gel-CNT nanocomposite films [74] were proved to behave as friendly platforms for enzyme encapsulation. 


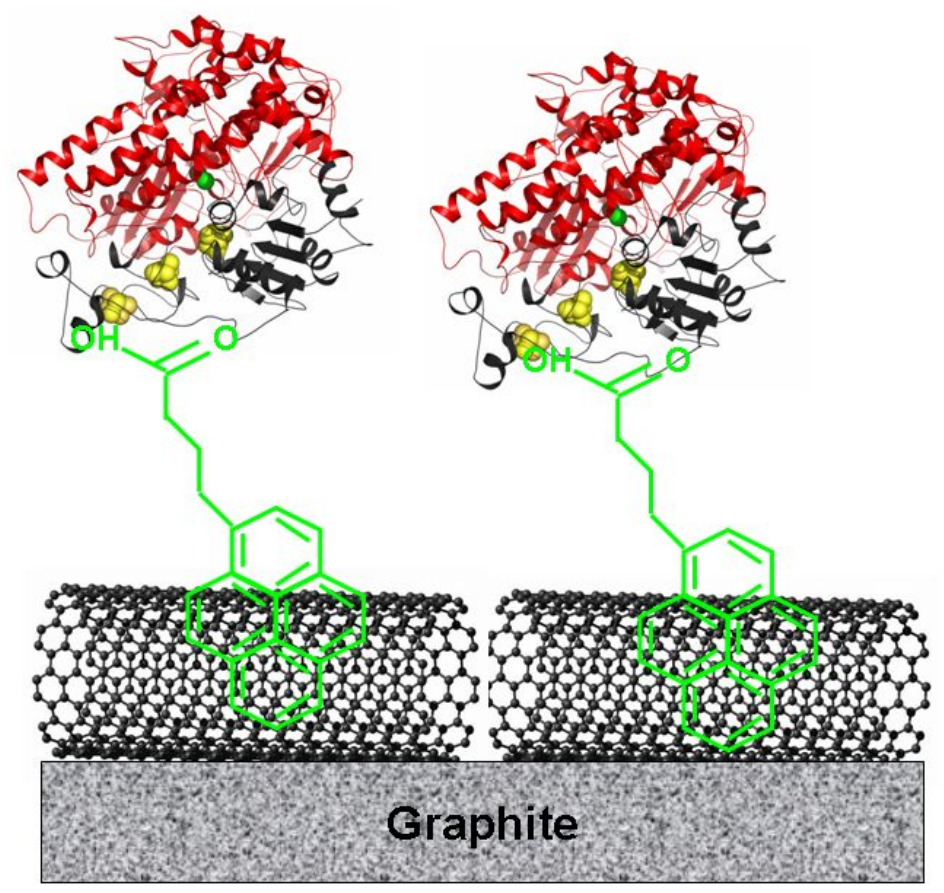

Figure 3. Schematic drawing of the build-up of enzyme on SWCNTs via $\pi-\pi$ interactions.

Many enzymes however cannot be electrically connected to the electrode interface and require redox mediator to electrochemically follow substrate conversion. In that case, electrode kinetics is mainly dependant on mediator kinetics, so that the choice of the redox mediator mainly impedes the power density. Another issue is that the mediator can be coimmobilized with the enzyme at the electrode, while still being capable of efficient interaction with the enzyme. CNTs have also been used for building networks enabling coimmobilization of enzymes and redox mediators. In that way, one of the most popular redox entities is osmium polymer which forms hydrogels with enzymes allowing both charge transfer reaction between enzyme and mediators and diffusion of substrate and product [75]. Composite CNT/osmium films were used To immobilize bacteria [76], or enzymes [77]. By optimizing the CNT and polymer amounts, enhanced current responses were obtained linked to a promotion of the electron transfer within the composite. Various phenothiazine derivatives were also used to form nanohybrids with CNTs acting as efficient redox mediator platforms [78-80]. Phenothiazine derivatives strongly adsorb onto CNTs leading to great enhancement of redox dye loading onto the electrode, but also to improved electrochemical sensing devices. Another strategy involves the use of a redox polymer as redox mediator platform. Electropolymerization of the redox conducting polymer onto CNTs enhances the amount of redox units and the electrical conductivity of the coating [81]. An 
interesting construction has also been obtained by immobilization of physiological cofactor onto CNT layers via $\pi-\pi$ interactions, then immobilization of the enzyme [82]. The covalent coupling between the enzyme and its natural cofactor which was immobilized onto CNTs was proved to be efficient towards mediated substrate catalysis. This overview of multiple architectures involving enzymes and CNTs highlights the deep efforts engaged in the last years for efficient biocatalyst immobilization that open avenues towards biotechnological devices.

\section{Carbon nanotubes for biological production of dihydrogen}

Apart from replacement of noble metal catalysts in fuel cells, a new green technology for production of dihydrogen is required. It currently relies on steam reforming of hydrocarbons under high temperature and pressure conditions, which starts from fossil fuels, thus producing greenhouse gases. Dihydrogen production via water electrolysis appears as a renewable solution given that the energy input comes from a renewable source, ideally solar energy. Many bacteria gain energy by the oxidation of dihydrogen assisted by a number of complex mechanisms. Various species evolve $\mathrm{H}_{2}$ under anaerobic conditions. This is also a human being process since bacteria in our digestive tract produce $\mathrm{H}_{2}$, though not detectable because immediately recycled by other bacteria. Photosynthetic organisms such as microalgae and cyanobacteria are very efficient in water splitting [83]. They possess photosensitizers for photon capture and charge separation, and enzymes for water oxidation to oxygen and water reduction to dihydrogen. This chemical activity relies on the expression of very efficient enzymes, called hydrogenases [84], which catalyze with high turn-over (one molecule of hydrogenase produces up to 9000 molecules of $\mathrm{H}_{2}$ per second at neutral $\mathrm{pH}$ and $37^{\circ} \mathrm{C}$ ) and low overvoltage the conversion of protons into dihydrogen and the oxidation of dihydrogen. The sequences of 450 hydrogenases are now available. Hydrogenases differ in size, structure, electrons donors. They also differ by their position in the cell (soluble in the periplasm, membrane-bound), and by their activity preferentially towards $\mathrm{H}_{2}$ oxidation or protons reduction. Hydrogenase active site is composed of non noble metals such as iron and nickel, unlike platinum catalyst necessary for the chemical electrolysis of water. Three distinct classes can be split which differ from the type of metal content in the active site: $[\mathrm{NiFe}],[\mathrm{FeFe}]$ and $[\mathrm{Fe}]$ hydrogenases. $[\mathrm{NiFe}]$ and $[\mathrm{FeFe}]$ hydrogenases possess dinuclear active centers which are connected through thiolate bridges. [NiFe] hydrogenase (Figure 4) is the most usual hydrogenase in microorganisms. It is composed of two subunits. The larger subunit harbors the [NiFe] active site. The small subunit contains FeS clusters. Electrons are transferred to the active site along these FeS clusters distant less than $10 \AA$ that act as a conductive line. [FeFe] hydrogenases are monomeric. In addition to the active site they contain additional domains which accommodate FeS clusters.

In order to use these biocatalysts for green dihydrogen production, two main research domains are currently concerned: the understanding of the catalytic mechanisms of $\mathrm{H}_{2}$ production, and the optimization of enzyme immobilization. Adsorption onto graphite electrodes $[85,86]$ was largely used to study the mechanisms by which hydrogenases produce $\mathrm{H}_{2}$. 
Grafting of hydrogenase onto gold electrode modified by thiolated Self-Assembled-Monolayer [87] allowed efficient proton reduction into dihydrogen in aqueous buffer solutions. Hydrogenase is also considered as a promising biocatalyst for photobiological production of dihydrogen when coupled to a photocatalyst [88]. Hybrid complexes of hydrogenases with $\mathrm{TiO}_{2}$ nanoparticles $[89,90]$ were studied for $\mathrm{H}_{2}$ production. The optimized system was shown to produce $\mathrm{H}_{2}$ at a turnover frequency of approximately $50\left(\mathrm{~mol} \mathrm{H}_{2}\right) \mathrm{s}^{-1}$ (mol total hydrogenase $)^{-1}$ at $\mathrm{pH} 7$ and $25^{\circ} \mathrm{C}$, even under the typical solar irradiation of a northern European sky. Cd-based nanorods [91, 92] were recently studied. The CdS nanorod/hydrogenase complexes photocatalyzed reduction of protons to $\mathrm{H}_{2}$ at a hydrogenase turnover frequency of $380-900 \mathrm{~s}^{-1}$ and photon conversion efficiencies of up to $20 \%$ under illumination at $405 \mathrm{~nm}$. Cd-based complexes allowed photoproduction of dihydrogen for a couple of hours, but still suffer from quick inhibition of hydrogenase.

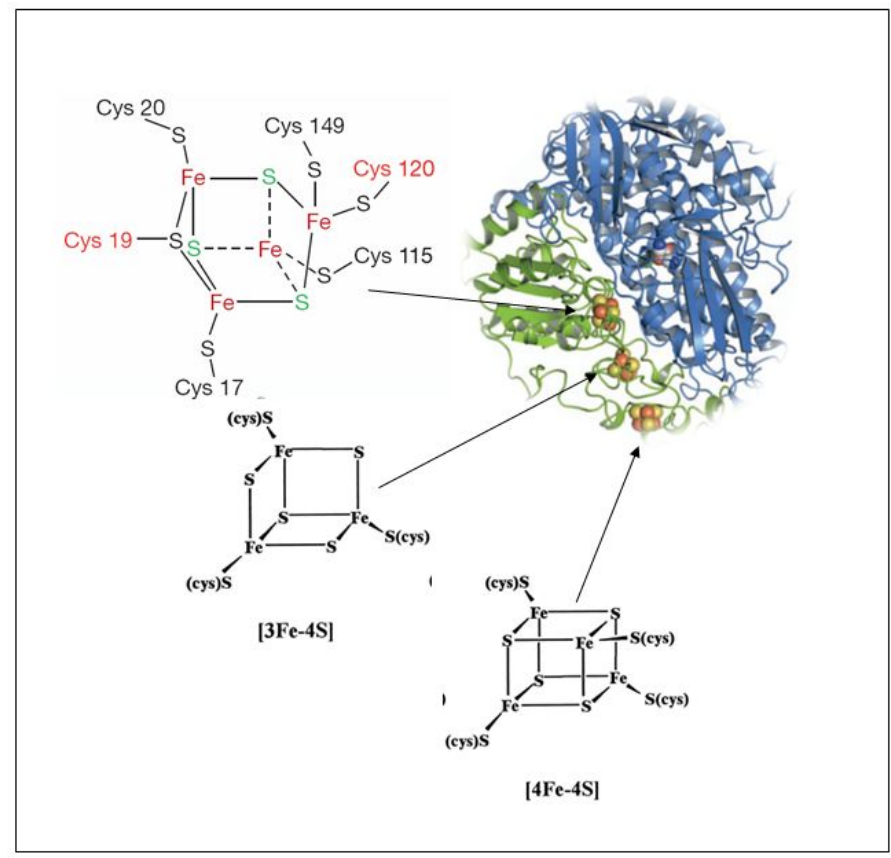

Figure 4. Structure of an oxygen-tolerant [NiFe] hydrogenase.

Although a very attractive way, little work has been done towards enhancement of green hydrogen production using CNTs. Three studies from the same group reported however catalytically active hydrogenase-SWCNT biohybrids [93, 94]. Surfactant-suspended SWCNTs were shown to spontaneously self-assemble with hydrogenase. Photoluminescence excitation and Raman spectroscopy showed that SWCNTs act as molecular wires to make electrical contact with at least one of the FeS electron relay. Hydrogenase was demon- 
strated to be strongly attached to the SWCNTs and to mediate electron injection into nanotubes. The displacement of the surfactant by hydrogenase to gain access to the SWCNTs was strongly suggested by photoluminescence studies. Furthermore, Raman studies of charge transfer complexes between hydrogenase and either metallic (m) or semiconducting (s) SWCNTs revealed a difference in oxygen deactivation of hydrogenase according to the SWCNT species. m-SWCNTs most probably interact with hydrogenase to produce a more oxygen-tolerant species. The study further suggested that purified m-SWCNTs or sSWCNTs, rather than mixed preparation, would be more suitable for hydrogenase-SWCNTs biohybrids. The formation of these catalytically active biohybrids in addition with the intrinsic properties developed by CNT networks on electrodes certainly accounts for the improved dihydrogen production observed in the following studies. Kihara et al. immobilized hydrogenase on a SWCNT-forest with a unique dense structure of vertically aligned millimetre-scale height SWCNTs [95]. Hydrogenase was demonstrated to spontaneously assemble between adjacent nanotubes. The maximum rate of dihydrogen production was reported to be $720 \mathrm{nmol} / \mathrm{min} /(\mathrm{mg}$ hydrogenase) and the electron transfer efficiency was estimated to be $32 \%$. It is two thousand fold higher than reported before using the same hydrogenase on Langmuir-Blodgett film [96]. Nevertheless, one key point in the development of biotechnological devices is the long term stability of enzymes. If these biological catalysts are very efficient in vivo, they often suffer from weak stability when extracted from their physiological environment. Enzyme encapsulation in silica-derived sol-gel materials has been demonstrated to stabilize many enzymes. This procedure was applied to hydrogenase [97]. The majority of hydrogenase was shown to be entrapped in the gel and protected against proteolysis. Hydrogenase/sol-gel pellets retained $60 \%$ of the specific mediated activity for $\mathrm{H}_{2}$ production displayed by hydrogenase in solution. The gel-encapsulated enzyme retained its activity for long periods, i.e. $80 \%$ of the activity after four weeks at room temperature. Notably, by doping the hydrogenase-containing sol-gel materials with MWCNTs Zadvorny et al. demonstrated a $50 \%$ increase in dihydrogen production [98]. Furthermore stabilization of hydrogenase was proved through encapsulation process.

One alternative for green hydrogen production is to synthesize metal complexes that mimic the active site of enzymes. Huge work has been done in that field in order to obtain bioinspired models that could produce $\mathrm{H}_{2}$ as efficiently as hydrogenase, while being much more stable [99]. The most performing complex involves mononuclear nickel diphosphine complex. This complex is inspired from the active sites of both [NiFe] and [FeFe] hydrogenases and displays remarkable catalytic proton reduction in organic solvent [100]. Le Goff et al. took benefice from this complex and from the results obtained by immobilization of hydrogenase on CNT networks [44]. The authors successfully immobilized the nickel complex onto carbon nanotube networks by covalent coupling [101]. Such construction was demonstrated to be very efficient for dihydrogen production in aqueous solution, evolving dihydrogen with overvoltage less than $20 \mathrm{mV}$ and exceptional stability. 


\section{Carbon nanotubes for biofuel cells: an attractive green alternative}

Beside researches towards decrease in chemical catalyst amount and discovery of less expensive catalysts (as alloys for example), a new concept emerged early in 1964 by Yahiro et al. [102]. A fuel cell was constructed using usual $\mathrm{O}_{2}$ reduction at platinum modified electrode in the cell cathodic compartment, but using glucose as a fuel in the anodic compartment. The innovative idea was the use of an enzyme specific for fuel oxidation instead of platinum. For glucose oxidation, glucose oxidase was tested as the anodic catalyst. The fuel cell delivered $30 \mathrm{nA} \mathrm{cm}^{-2}$ at $330 \mathrm{mV}$... a very low power density indeed but the proof of concept of biofuel cell was born. Generally speaking these biofuel cells function as fuel cells but used enzymes instead of noble metals as catalysts (Figure 5). They are referred as enzymatic biofuel cells. Microorganisms can also be used as catalysts, defining microbial fuel cells. Microbial biofuel cells use the metabolism of microorganisms under anaerobic conditions to oxidize fuel [103-104]. Although a promising concept, little is known yet about the mechanisms by which fuel is oxidized at the anode. The involvement of nanowires, electron transfer mediators, either membrane-bound or excreted, is supposed to be responsible for the cell current. Enzymatic biofuel cells are however more efficient because no mass transfer limitations across the cell membrane exist.

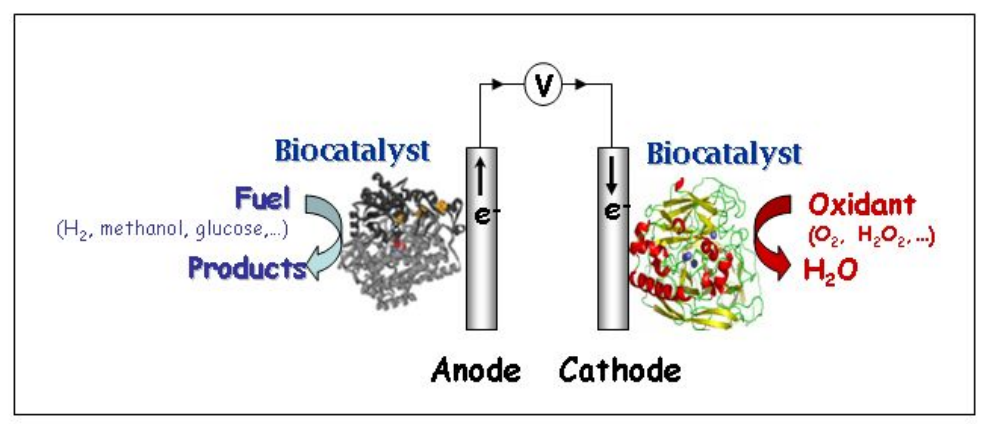

Figure 5. Schematic representation of an enzymatic biofuel cell.

The advantages of enzymatic biofuel cells over fuel cells are multiple. Biocatalysts are widespread, then a priori inexpensive, and biodegradable. Enzymes are highly efficient and specific to their substrates. The substrate specificity decreases reactant cross-over, and might theoretically allow to design fuel cells with no membrane between the anodic and cathodic compartments. Both costs are reduced and the design is simplified. A large variety of fuels and oxidants can be used to feed the biofuel cells, as opposed to the poor available fuels and oxidant in classical fuel cells (dihydrogen, methanol, oxygen). Indeed, many enzymes are nowadays characterized which differ by their natural abundant substrates. Dihydrogen, but also various inexpensive sugars can thus be used as efficient fuels at the anode. Furthermore, the involvement of cascades of enzymes can enhance the cell performance because of the summation of the electrons from each enzymatic reaction [105]. Finally, biofuel cells can 
deliver power under soft working conditions, as enzymes usually perform their enzymatic reactions at mild $\mathrm{pH}$ and temperature. Nevertheless, some extremophilic enzymes operate in extreme acidic or basic $\mathrm{pH}$, as well as at high temperatures (around $90^{\circ} \mathrm{C}$ ) or high pressure, offering the possibility to develop biofuel cell devices for special applications requiring extreme working conditions [106]. The applications of biofuel cells are still in their infancy. They are mainly thought to power small portable devices. Remarkable progress has been reported for implantable biofuel cells during the last year to power drug pumps, glucose sensors, vision devices [107-109].

The most common redox couple that has been used in biofuel cells is sugar/ $\mathrm{O}_{2}$, essentially because of sugar and $\mathrm{O}_{2}$ abundance in nature and their essential role in living metabolism. In particular, glucose is an important metabolite and a source of energy for many living organisms. In that field, CNTs have been widely used, both at the anode and cathode. Glucose $/ \mathrm{O}_{2}$ biofuel cell is thus a very pertinent investigation field to investigate the role of CNTs. A view of some typical results is presented in Table 2.

\begin{tabular}{|c|c|c|c|}
\hline $\begin{array}{c}\text { Enzymes } \\
\text { Anode / Cathode }\end{array}$ & $\begin{array}{c}\text { Mediators } \\
\text { Anode / Cathode }\end{array}$ & $\begin{array}{l}\text { Power density } \\
\qquad \mu \mathrm{W} \mathrm{cm}{ }^{-2}\end{array}$ & Ref \\
\hline Gox / Laccase & Ferrocene / - & 15 & [111] \\
\hline $\mathrm{GDH} / \mathrm{BOD}$ & PQQ / - & 23 & [82] \\
\hline $\mathrm{Gox} / \mathrm{Pt}$ & Ferrocenecarboxaldehyde / - & 51 & {$[112]$} \\
\hline $\mathrm{GDH} / \mathrm{BOD}$ & Poly(brilliant cresyl blue) / - & 54 & {$[113]$} \\
\hline GDH / laccase & Azine dies / - & 58 & [114] \\
\hline Gox / Pt & Benzoquinone / - & 77 & {$[52]$} \\
\hline Gox / Laccase & Ferrocene / ABTS & 100 & [115] \\
\hline Gox / BOD & Ferrocene methanol / ABTS & 120 & [116] \\
\hline GDH / Laccase & $-1-$ & 131 & {$[117]$} \\
\hline $\mathrm{CDH} / \mathrm{Pt}$ & Os complex / - & 157 & [118] \\
\hline Gox / Laccase & $-1-$ & 1300 & {$[119]$} \\
\hline
\end{tabular}

Gox: Glucose oxidase; GDH: Glucose dehydrogenase; BOD: Bilirubin oxidase; ABTS: 2, 2'-azino-bis(3-ethylbenzothiazoline-6-sulfonate) diammonium; $\mathrm{CDH}$ : cellobiose dehydrogenase.

Table 2. Performances of glucose $/ \mathrm{O}_{2}$ fuel cells.

Data highlight that kinetics of bioelectrochemical reactions, thus power density, largely depends on the experimental conditions, i.e. enzyme and mediators, $\mathrm{T}^{\circ}, \mathrm{pH}$, concentration of substrate, electrolyte and type of electrode construction. Highest values are obtained with mediatorless fuel cells, reaching power densities upper than $1 \mathrm{~mW} \mathrm{~cm}^{-2}$ which is sufficient to power small electrical devices. It appears that direct connection of copper enzymes, namely laccase or BOD, for oxygen reduction at the cathode can be quite easily obtained with the help of CNT network. Direct connection of enzymes for glucose oxidation is conversely hardly observed, even on CNT coatings. From literature examination direct connection of 
Gox at electrode interfaces is still controversial. Due to the peculiar structure of Gox, a dimer with flavin adenine dinucleotide active site buried within a thick and isolated protein shell, it is understandable that electrical connection of Gox could be unexpected. A recent work concluded that CNTs were capable to electrically connect Gox, but this connection was unfruitful for glucose catalytic oxidation [110].

\section{Carbon nanotubes for bioelectrooxidation of $\mathrm{H}_{2}$ : towards $\mathrm{H}_{2} / \mathrm{O}_{2}$ biofuel cells}

We already described above hydrogenases, the enzymes that convert with high specificity and efficiency protons into dihydrogen. Most of these biocatalysts are also efficient in the oxidation of dihydrogen into protons. Consequently this allows to imagine biofuel cells in which the fuel would be dihydrogen, exactly as in PEM fuel cells. As hydrogenases are able to oxidize dihydrogen with very low overvoltage, the open circuit voltage for the biofuel cell using oxygen at the cathode, is expected to be not far from the thermodynamic one, i.e. 1.23 V. Hence, high power densities are expected, provided that a strong and efficient electrical connection between hydrogenase and electrode can be achieved. Simple adsorption of hydrogenase was performed in a first step, because it allowed a direct oxidation of dihydrogen without any redox mediators [120]. Catalytic mechanisms associated with dihydrogen oxidation at the active site were largely studied. The effect of strong hydrogenase inhibitors such as oxygen and $\mathrm{CO}$ were explored by this mean, leading to nice developments in engineering of more tolerant hydrogenases [121] or use of naturally resistant hydrogenases [122, 123]. However, this immobilization procedure relies on a monolayer of enzyme, which furthermore suffers from quick desorption. Otherwise, multilayer enzymatic films require a redox mediator so that even the last layer far from the electrode could be connected. Other immobilization processes are thus needed, that can favor an enhancement in both the amount of connected hydrogenases as well as their stability, while preserving their functionality.

Carbon nanotube networks constituted technological breakthroughs in that way. All the recent developments using immobilization of hydrogenases onto carbon nanotubes point out improved catalytic currents essentially related to an increase in the active area of the electrode. The respective role of metallic-SWCNTs against semiconducting one was explored for dihydrogen oxidation by immobilized hydrogenase [124]. A higher oxidation process was revealed when the nanotube mixture was enriched in metallic SWCNT. The study furthermore suggested no need of oxygenated SWCNTs for efficient anchoring of hydrogenases. The catalytic current enhancement was claimed to be due to an increase in active electrode surface area and an improved electronic coupling between hydrogenase redox active sites and the electrode surface. In most cases, however, CNTs are used as a mixture of metallic and semi-conducting tubes. Oxidation of the mixture yields the defects and functionalities described above in this review. Advantage is gained due to these chemical functions quite easily generated on the surface of the carbon nanotubes. Electrodes modified by carbon nanotubes are thus expected to offer numerous anchoring sites for stable hydrogenase immobilization. The literature provides a few examples of efficient immobili- 
zation of hydrogenase on carbon nanotubes coatings bearing various functionalities. Both SWCNTs and MWCNTs are used. Notably, more and more articles are devoted nowadays to this domain in hydrogenase research. A bionanocomposite made of the hydrogenase, MWCNTs and a thiopyridine derivative was proved to form stable monolayers when transferred by Langmuir-Blodgett method on indium tin oxide electrode surfaces [125]. A greater amount of electroactive hydrogenase towards dihydrogen oxidation was demonstrated to be adsorbed on the Langmuir-Blodgett films. De Lacey and co-workers grew MWCNTs on electrode by chemical vapor deposition of acetylene [65]. A high density of vertically aligned carbon nanotubes was obtained, which were functionalized by electroreduction of a diazonium salt for covalent binding of hydrogenase. High coverage of electroactive enzyme was measured, suggesting that almost all the functionalized CNT surface was accessible to hydrogenase. Great stabilization of the catalytic current for $\mathrm{H}_{2}$ oxidation was obtained, with no decrease in current density after one month. Another work by Heering and coworkers studied a gold electrode pre-treated by polymyxin then a multilayer of carbon nanotubes [126]. Polymyxin was shown to help in the stable attachment of hydrogenase on the gold electrode. Using adsorption of hydrogenase on a nanotube layer pretreated with polymyxin the current density for $\mathrm{H}_{2}$ oxidation was an order of magnitude higher than at the gold electrode only modified by polymixin. This result was supposed to origin from greater surface area even though only the top of the nanotube layer was supposed to be accessible to the enzyme. The catalytic current was stable with time, at least for two hours under continuous cycling, and several days upon storage under ambient conditions. AFM visualization of hydrogenase immobilized onto polymyxin-treated SWCNT layer on $\mathrm{SiO}_{2}$ revealed that hydrogenase was structurally intact and preferentially adsorbed on the sidewalls of the CNTs rather than on $\mathrm{SiO}_{2}$ [126].

In our laboratory, we immobilized the [NiFe] hydrogenase from a mesophilic anaerobic bacterium (the sulfate reducing bacterium Desulfovibrio fructosovorans Df) by adsorption onto SWCNT films [44]. The current for direct $\mathrm{H}_{2}$ oxidation was shown to increase with the amount of SWCNTs in the coating (Figure 6).

Because non-turnover signals were not detected for hydrogenase in these conditions, the increase in surface area was evaluated using a redox protein as a probe. It was shown that SWCNTs induced one order larger surface area. The same hydrogenase was entrapped in methylviologen functionalized polypyrrole films coated onto SWCNTs and MWCNTs [127]. Although no direct electrical hydrogenase connection was observed, an efficient dihydrogen oxidation through a mediated process occurred. It was concluded that the entrapment of hydrogenase into the redox polymer coated onto CNTs combined the electron carrier properties of redox probes, the flexibility of polypyrroles, and the high electroactive area developed by CNTs. The reason why no direct connection could be observed is however not clearly understood yet. In our group we handled immobilization of hydrogenase on a film obtained by electropolymerization of a phenothiazine dye on a SWCNT coating [81]. The phenothiazine dye was shown to be able to mediate dihydrogen oxidation but also to serve as an anchor for the enzyme when adsorbed or when electropolymerized. Higher current density than in the absence of SWCNT was observed. In addition, a wider potential window for dihydrogen oxidation was reached as well as very stable electrochemical signals with 
time. We postulated that the conductive polymer which was electropolymerized onto CNTs could play a multiple role: enhancement of the electroactive surface area, enhancement of redox mediator units due to phenothiazine monomers entrapped in the polymer matrix, enhancement of hydrogenase anchorage sites. We have already mentioned in this review the advantages of a direct electron transfer over a mediated one for $\mathrm{H}_{2}$ oxidation, including gain in over-potential values, less interferences due to enzyme specificity, absence of redox mediators that could be difficult to co-immobilize with the enzyme... Functionalized carbon nanotube films were evaluated in our group as platforms for various hydrogenases, that present a very different environment of FeS cluster electron relay. Dihydrogen oxidation was studied at gold electrodes modified with functionalized self-assembled-monolayers [128]. As expected, dihydrogen oxidation process was demonstrated to be driven by electrostatic or hydrophobic interactions according to the specific environment of the surface electron relay. Interestingly, at CNT coatings, although CNTs were negatively charged, direct electrical connection of hydrogenases that present a negatively charged patch around the FeS surface electron relay was observed [44, 123]. In other words, despite unfavourable electrostatic interactions, direct electron transfer process for dihydrogen oxidation was achieved. One important conclusion was that on such CNT films, the nanometric size of the CNTs allows a population of hydrogenases to be directly connected to a neighbouring nanotube, hence allowing direct electron transfer for $\mathrm{H}_{2}$ oxidation, whatever the orientation of the enzyme.

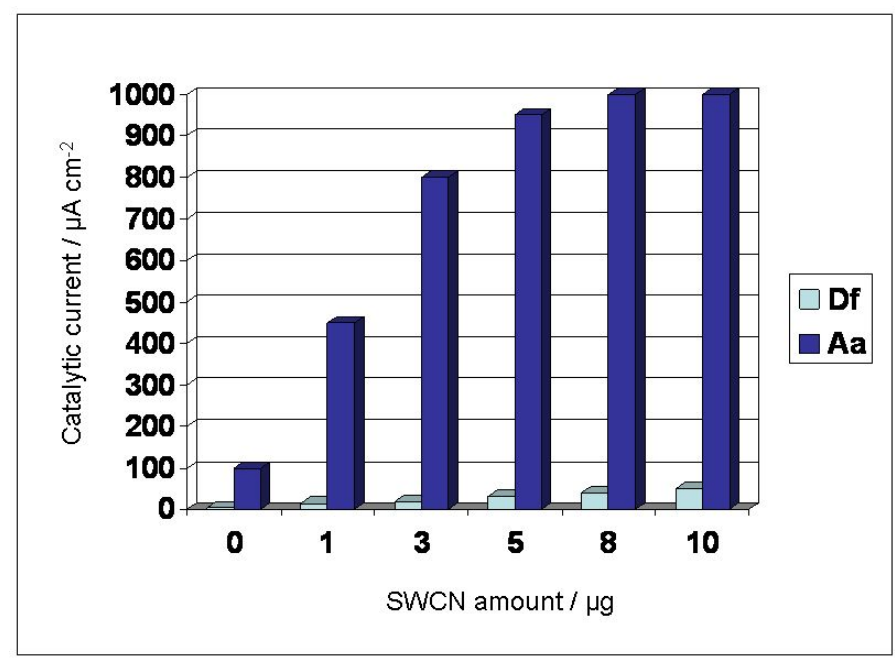

Figure 6. Comparative evolution of the catalytic current for dihydrogen oxidation with the amount of SWCNTs deposited at a graphite electrode in the case of hydrogenases from Aquifex aeolicus (Aa) or Desulfovibrio fructosovorans (Df). Catalytic currents are measured using voltammetry under $\mathrm{H}_{2}$ at 60 and $25^{\circ} \mathrm{C}$ for $\mathrm{Aa}$ and Df respectively.

However, the extreme oxygen sensitivity of hydrogenases used in the former studies yielded an intensive research towards more resistant enzymes. During the last years, four [NiFe] 
membrane-bound hydrogenases have been discovered from aerobic or extremophilic organisms [128, 129-132]. They have been demonstrated to oxidize $\mathrm{H}_{2}$ in the presence of oxygen and $\mathrm{CO}$. The crystallographic structure of three of them has been resolved, showing that an uncommon [4Fe-3S] cluster proximal to the active site prevents deleterious oxygen attack. Of course, the sensitivity to oxygen, and also to $\mathrm{CO}$, of most hydrogenases known before was a strong limitation for their potential use in biotechnological devices. Therefore these resistant biocatalysts open new avenues towards a biohydrogen economy. No doubt that these researches will increase in the next future. To date, two main studies report the immobilization of resistant hydrogenase on CNT-modified electrodes. Krishnan et al. very recently modified MWCNTs by pyrenebutyric acid, and demonstrated it was an efficient platform for stable $\mathrm{O}_{2}$-resistant hydrogenase linkage [133]. In our group, original use of a hyperthermophilic $\mathrm{O}_{2}$ - and CO-resistant hydrogenase allowed the increase in the catalytic current for direct $\mathrm{H}_{2}$ oxidation on a large range of temperature up to $70^{\circ} \mathrm{C}$. Attempts to enhance the number of electrically connected hydrogenase succeeded by use of coatings of chemically oxidized SWCNTs [123]. Values as high as $1 \mathrm{~mA} \mathrm{~cm}^{-2}$ were reached depending on the amount of SWCNTs used in the coating (Figure 6). For the lowest amounts of SWCNTs, the increase in the catalytic current was demonstrated to be essentially due to the increase in surface area. However the catalytic current rapidly reached a plateau, although the peak current for the redox probe still increased, suggesting rapid saturation of the surface.

\section{Design of a $\mathrm{H}_{2} / \mathrm{O}_{2}$ biofuel cell based on carbon nanotubes-modified electrodes}

$\mathrm{H}_{2} / \mathrm{O}_{2}$ biofuel cells did not get much attention before $\mathrm{O}_{2}$ and $\mathrm{CO}$ resistant hydrogenases were proved to be efficient for $\mathrm{H}_{2}$ oxidation when immobilized onto electrode surfaces. Even though more and more efficient hydrogenase immobilization procedures are nowadays reported, few $\mathrm{H}_{2} / \mathrm{O}_{2}$ biofuel cells are described. An early study by Armstrong's group in 2006 [134] demonstrated that simple adsorption on graphite electrode of hydrogenase at the anode and laccase (a copper protein for $\mathrm{O}_{2}$ reduction) at the cathode, allowed a wristwatch to run for $24 \mathrm{~h}$. Power density of around $5 \mu \mathrm{W} \mathrm{cm} \mathrm{cm}^{-2}$ at $500 \mathrm{mV}$ was delivered with no membrane between the two compartments providing hydrogenase was extracted from Ralstonia metallireducens. As this is an aerobic bacterium, the result underlined that the $\mathrm{H}_{2} / \mathrm{O}_{2}$ biofuel cell could operate only with $\mathrm{O}_{2}$ resistant hydrogenase. In 2010, the same group improved the device by using another $\mathrm{O}_{2}$ resistant hydrogenase from Escherichia coli and bilirubin oxidase (BOD), another copper protein more efficient than laccase towards oxygen reduction because being able to function at neutral $\mathrm{pH}$ [135]. The oxygen reductase was covalently linked to the graphite electrode which had been modified by diazonium salt reduction. The power density was enhanced compared to the former study reaching $63 \mu \mathrm{W} \mathrm{cm}{ }^{-2}$. But most of all, this work provided a nice understanding of the operating conditions of such $\mathrm{H}_{2} / \mathrm{O}_{2}$ fuel cells involving hydrogenase as anode catalyst.

Due to the understanding of how hydrogenases could be efficiently connected at CNTcoated electrodes, a huge step jumped over very recently. First, using covalent attach- 
ment of both $\mathrm{O}_{2}$ resistant hydrogenase and BOD on pyrene derivative functionalized MWCNTs, a membrane-less biofuel cell was designed fed with a non-explosive 80/20 dihydrogen/air mixture [133]. This biofuel cell displayed quite a good stability with time and a much higher power density than reported before. Indeed, an average power density of

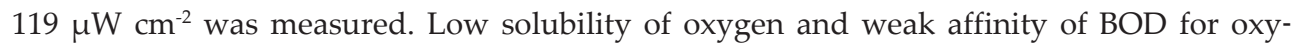
gen was shown to limit the cathodic current. Secondly in our group, a more performant $\mathrm{H}_{2} / \mathrm{O}_{2}$ mediatorless biofuel cell was constructed based on one step covalent attachment directly on SWCNTs of an hyperthermophilic $\mathrm{O}_{2}$ resistant hydrogenase at the anode and BOD at the cathode [136] (Figure 7).
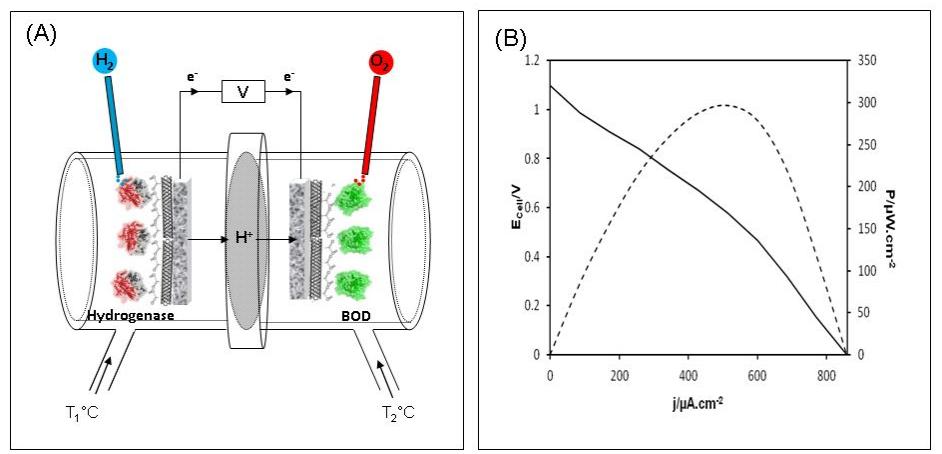

Figure 7. (A) Schematic representation of $\mathrm{H}_{2} / \mathrm{O}_{2}$ biofuel cell with $\mathrm{O}_{2}$ resistant hydrogenase at the anode and bilirubin oxidase (BOD) at the cathode. Each half cell, separated by a Nafion ${ }^{\circledast}$ membrane, is independently thermoregulated with waterbaths. (B) Performance of the $\mathrm{H}_{2} / \mathrm{O}_{2}$ biofuel cell.

Taking advantage of temperature, the biofuel cell delivered power densities up to $300 \mu \mathrm{W}$ $\mathrm{cm}^{-2}$ at $0.6 \mathrm{~V}$ with an $\mathrm{OCV}$ of $1.1 \mathrm{~V}$, which is the highest performance ever reported. Furthermore, promising stability of the biofuel cell during $24 \mathrm{~h}$ of continuous use lets us consider this device as an alternative power supply for small portable applications. The analysis of the fuel cell parameters during polarization, allows us to define the potential window in which the fuel cell fully operates. Interestingly, in Armstrong's group [135] and in our group, different approaches on the settings of biofuel cell working conditions, led to similar observations of an unexpected increasing anodic potential. This high oxidizing potential generates an inactive state of hydrogenase active site. It is worth noticing that this hydrogenase inactivation occurred under anaerobic conditions in our group while it was under aerobic conditions in Armstrong's group. Consequently, dramatic loss in power densities was observed. By applying negative potential to the anode, and thus providing electrons to the active site, we were unable to reactivate hydrogenase. Another protocol used by Armstrong, consisted to add a second hydrogenase coated anode, unconnected to the system but present in the anodic half-cell which was consequently unaffected by the oxidizing potential but still in presence of $\mathrm{O}_{2}$. This second anode, under $\mathrm{H}_{2}$ oxidation was used as an electron supplier and connected to the first electrode. This procedure reactivated hydrogenase and allowed 
full recovery of OCV. It is of relevant interest to overcome hydrogenase inactivation in $\mathrm{H}_{2} / \mathrm{O}_{2}$ biofuel cell.

\section{Future directions}

As reviewed in this chapter, many of the CNTs based technologies are promising for the development of a green hydrogen economy. Not only abiotic dihydrogen storage, but also microbial dihydrogen production and use of this green dihydrogen in biofuel cells can take advantages of the outstanding properties of CNTs. In all these applications, CNTs appear to play multiple roles including increase in surface area, increase in electron transfer rate, increase in directly connected enzymes. Possible protection against oxygen damage of enzymes has even been strongly suggested. Use of CNTs thus allows to architecture threedimensional nanostructured interfaces which can be an alternative to strictly orientated proteins or enzymes for high direct electron transfer interfacial processes. The ease in obtaining tuned surface functionalizations is one of the very attracting points in view of the development of efficient bioelectrodes.

This is in particular the case for biofuel cells using dihydrogen as a fuel. During the last years, tremendous research on hydrogenase, the key enzyme for dihydrogen conversion, has led to the discovery, then control of some hydrogenases presenting properties that allow their use in biotechnological devices. During this year, based on these new resistant enzymes and on improved knowledge of how CNTs can enhance direct current densities, two $\mathrm{H}_{2} / \mathrm{O}_{2}$ biofuel cells have been reported. Although these biofuel cells constitute the first device using hydrogenases, they already deliver sufficient power density for small portable applications. No doubt that this research field will gain more and more interest in a next future.

However, various directions might be followed to further improve the biological system in such a way it could be commercially available. One is the enhancement of long-term stability of the device, which is obviously the critical point shared by (bio)fuel cells, yet. Search for more stable enzymes in the biodiversity or enzyme engineering has to be explored. Protection of enzymes by various encapsulation procedures could be another solution given efficient interfacial electron transfer can be reached. The use of whole microorganisms with controlled and driven metabolism, or at least immobilization of naturally encapsulated enzymes will be a next step. As an example, reconstitution of proteoliposomes with a membrane-bound hydrogenase was proved to enhance the stability of the enzyme [137]. This could be a novel route for preserving enzymes in their physiological environment, hence enhancing their stability. New enzymes, with outstanding properties $\left(\mathrm{T}^{\circ}, \mathrm{pH}\right.$, inhibitors, substrate affinity...) have to be discovered and studied. Notably, two very recent publications report on a new thermostable bilirubin oxidase and a tyrosinase which present outstanding resistances to serum constituents [138, 139]. These two new enzymes appear to be able to efficiently replace the currently used BOD for implantable applications of biofuel cells.

More sophisticated materials interfaces, constituted of mixtures of CNTs with other conducting materials could bring a hierarchical porosity necessary for both enzyme immobiliza- 
tion and substrate diffusion. Carbon fibers, mesoporous carbon templates could be used to build very interesting new electrochemical interfaces. This diversity in potential carbon materials for efficient enzyme immobilization would be a key step to go through the difficulties linked to CNTs, i.e. effective cost for separation and purification as well as possible toxicity. Finally, to avoid the membrane between the cathodic and anodic compartments, and build a miniaturized biofuel cell, unusual cell designs, such as microfluidic or flow-through systems, are likely to open new avenues. All these future developments will certainly require a multidisciplinary approach, coupling electrochemists with biochemists and physicists, and coupling methods such as electrochemistry and spectrometry, electrochemistry and molecular genetics or electrochemistry and materials chemistry. This multidisciplinary willingness will help in the elucidation of the interactions between enzymes and nanostructured materials at the nanoscale and yield innovative nanobiotechnological approaches and applications.

\section{Acknowledgements}

We gratefully acknowledge the contribution of Marielle Bauzan (Fermentation Plant Unit, IMM, CNRS, Marseille, France) for growing the bacteria, Dr Marianne Guiral, Dr Marianne Ilbert and Pascale Infossi for fruitful discussions. This work was supported by research grants from CNRS, Région PACA and ANR.

\section{Author details}

Anne De Poulpiquet, Alexandre Ciaccafava, Saïda Benomar,

Marie-Thérèse Giudici-Orticoni and Elisabeth Lojou*

*Address all correspondence to: lojou@imm.cnrs.fr

Bioénergétique et Ingénierie des Protéines, CNRS - AMU - Institut de Microbiologie de la Méditerranée, France

\section{References}

[1] Verne, J. (1874 ). L'île mystérieuse.

[2] Grove, W. (1838). On a new voltaic combination. Philosophical Magazine and Journal of Science, 13, 430.

[3] Charlou, J. L., Donval, J. P., Konn, C., Ondréas, H., Fouquet, Y., Jean-Baptiste, P., \& Fourré, E. (2010). High production and fluxes of $\mathrm{H}_{2}$ and $\mathrm{CH}_{4}$ and evidence of abiotic hydrocarbon synthesis by serpentinization on ultramafic-hosted hydrothermal systems on Mid-Atlantic Ridge. Rona P., Devey C., Dyment J. Murton B. Editors,. "Di- 
versity of hydrothermal systems on slow spreading ocean ridges" Edited by AGU Geophysical monograph series, 188, 265-296.

[4] Oberlin, A., Endo, M., \& Koyama, T. (1976). Filamentous growth of carbon through benzene decomposition. Journal of Crystal Growth, 32(3), 335-349.

[5] Iijima, S. (1991). Helical microtubules of graphitic carbon. Nature, 354-56.

[6] Saito, R., Dresselhaus, G., \& Dresselhaus, M. (1998). Physical Properties of Carbon Nanotubes. Imperial College Press, London.

[7] Kirk, Othmer. (1996). Encyclopedia of Chemical Technology, (4th ed.). Wiley and Sons, New York.

[8] Heitner-Wirguin, C. (1996). Recent advances in perfluorinated ionomer membranes: structure, properties and applications. Journal of Membrane Science, 120(1), 1-33.

[9] Cracknell, J., Vincent, K., \& Armstrong, F. (2008). Enzymes as working or inspirational electrocatalysts for fuel cells and electrolysis. Chemical Review, 108(7), 2439-2461.

[10] Guiral, M., Prunetti, L., Aussignargues, C., Ciaccafava, A., Infossi, P., Ilbert, M., Lojou, E., \& Giudici-Orticoni, M. T. (2012). The hyperthermophilic bacterium Aquifex aeolicus: from respiratory pathways to extremely resistant enzymes and biotechnological applications. Advances in Microbiological Physiology; to be edited.

[11] Ivanov, I., Vidakovic-Koch, T., \& Sundmacher, K. (2010). Recent Advances in Enzymatic Fuel Cells:. Experiments and Modeling Energies, 3(4), 803-846.

[12] Tran, P., Artero, V., \& Fontecave, M. (2010). Water electrolysis and photoelectrolysis on electrodes engineered using biological and bio-inspired molecular systems. Energy E Environmental Science, 3(6), 727-747.

[13] Lojou, E. (2011). Hydrogenases as catalysts for fuel cells: Strategies for efficient immobilization at electrode interfaces. Electrochimica Acta, 56(28), 10385-10397.

[14] Schnorr, J. M., \& Swager, T. M. (2011). Emerging Applications of Carbon Nanotubes. Chemistry of Matererials, 23(3), 646-657.

[15] Iijima, S., \& Ichihashi, T. (1993). Single-shell carbon nanotubes of 1-nm diameter. Nature, 363, 603-605.

[16] Dresselhaus, M., Dresselhaus, G., \& Jorio, A. (2004). Unusual properties and structure of carbon nanotubes. Annual Review of Material Research, 34-247.

[17] Botzung, M., Chaudourne, S., Gillia, O., Perret, C., Latroche, M., Percheron-Guegan, A., \& Marty, P. (2008). Marty Simulation and experimental validation of a hydrogen storage tank with metal hydrides. International Journal of Hydrogen Energy, 33(1), 98-104.

[18] Vajo, J., Li, W., \& Liu, P. (2010). Thermodynamic and kinetic destabilization in $\mathrm{LiBH}_{4} / \mathrm{Mg}_{2} \mathrm{NiH}_{4}$ : promise for borohydride-based hydrogen storage. Chemical Communications, 46(36), 6687-6689. 
[19] Li, C., Peng, P., Zhou, D., \& Wan, L. (2011). Research progress in $\mathrm{LiBH}_{4}$ for hydrogen storage: A review. International Journal of Hydrogen Energy, 36(22), 14512-14526.

[20] Yao, X., Wu, C., Du, A., Lu, G., Cheng, H., Smith, S., Zou, J., \& He, Y. (2006). Mgbased nanocomposites with high capacity and fast kinetics for hydrogen storage. Journal of Physical Chemistry B, 110(24), 11697-11703.

[21] Luo, Y., Wang, P., Ma , L. P, \& Cheng, M. (2007). Enhanced hydrogen storage properties of $\mathrm{MgH}_{2}$ co-catalyzed with $\mathrm{NbF}_{5}$ and single-walled carbon nanotubes. Scripta Materialia, 56(9), 765-768.

[22] Wu, C., Wang, P., Yao, X., Liu, C., Chen, D., Lu, G., \& Cheng, H. (2006). Effect of carbon/noncarbon addition on hydrogen storage behaviour of magnesium hydride. Journal of Alloys Compounds, 414-259.

[23] Dillon, A., Jones, K., Bekkedahl, T., Kiang, C., Bethune, D., \& Heben, M. (1997). Storage of hydrogen in single-walled carbon nanotubes. Nature, 386(6623), 377-379.

[24] Ding, F., \& Yakobson, B. (2011). Challenges in hydrogen adsorptions: from physisorption to chemisorption. Frontiers of Physics, 6(2), 142-150.

[25] Nikitin, A., Li, X., Zhang, Z., Ogasawara, H., Dai, H., \& Nilsson, A. (2008). Hydrogen storage in carbon nanotubes through the formation of stable C-H bonds. Nano Letters, $8(1), 162-167$.

[26] Sahaym, U., \& Norton, M. (2008). Advances in the application of nanotechnology in enabling a hydrogen economy. Journal of Material Sciences, 43(16), 5395-549.

[27] Tang, Z., Poh, C., Lee, K. K., Tian, Z., Chua, D., \& Lin, J. (2010). Enhanced catalytic properties from platinum nanodots covered carbon nanotubes for proton-exchange membrane fuel cells. Journal of Power Sources, 195(1), 155-159.

[28] Lin, J., Kamavaram, V., \& Kannan, A. (2010). Synthesis and characterization of carbon nanotubes supported platinum nanocatalyst for proton exchange membrane fuel cells. Journal of Power Sources, 195(2), 466-470.

[29] Kongkanand, A, Kuwabata, S, Girishkumar, G, \& Kamat, P. (2006). Single-wall carbon nanotubes supported platinum nanoparticles with improved electrocatalytic activity for oxygen reduction reaction. Langmuir, 22(5), 2392-2396.

[30] Lin, J., Mason, C., Adame, A., Liu, X., Peng, X., \& Kannan, A. (2010). Synthesis of Pt nanocatalyst with micelle-encapsulated multi-walled carbon nanotubes as support for proton exchange membrane fuel cells. Electrochimica Acta, 55(22), 6496-6500.

[31] Lee, C., Ju, Y. C., Chou, P. T., Huang, Y. C., Kuo, L. C., \& Oung, J. C. (2005). Preparation of $\mathrm{Pt}$ nanoparticles on carbon nanotubes and graphite nanofibers via self-regulated reduction of surfactants and their application as electrochemical catalyst. Electrochemistry Communications, 7(4), 453-458.

[32] He, D., Zeng, C., Xu, C., Cheng, N., Li, H., \& Mu, S. (2011). Polyaniline-Functionalized Carbon Nanotube Supported Platinum Catalysts. Langmuir, 27(9), 5582-5588. 
[33] Ludwig, R., Harreither, W., Tasca, F., \& Gorton, L. (2011). Cellobiose Dehydrogenase: A Versatile Catalyst for Electrochemical Applications. ChemPhysChem., 11(13), 2674-2697.

[34] Cang-Rong, J., \& Pastorin, G. (2009). The influence of carbon nanotubes on enzyme activity and structure: investigation of different immobilization procedures through enzyme kinetics and circular dichroism studies. Nanotechnology, 20(25), 255102.

[35] Matsuura, K., Saito, T., Okasaki, T., Oshima, S., Yumura, M., \& Iijima, S. (2006). Selectivity of water-soluble proteins in single-walled carbon nanotube dispersions. Chemical Physics Letters, 429(4-6), 497-502.

[36] Patolsky, F., Weizmann, Y, \& Willner, I. (2004). Long-range electrical contacting of redox enzymes by SWCNT connectors. Angewandte Chemistry International Edition, 43(16), 2113-2117.

[37] Liu, J., Chou, A., Rahmat, W., Paddon-Row, M., \& Gooding, J. (2005). Achieving direct electrical connection to glucose oxidase using aligned single walled carbon nanotube arrays. Electroanalysis, 17(1), 38-46.

[38] Wang, J. (2005). Carbon-nanotube based electrochemical biosensors: A review. Electroanalysis, 17(1), 7-14.

[39] Wildgoose, G., Banks, C., Leventis, H., \& Compton, R. (2006). Chemically modified carbon nanotubes for use in electroanalysis. Microchimica Acta, 152(3-4), 187-214.

[40] Dumitrescu, I., Unwin, P., \& Macpherson, J. (2009). Electrochemistry at carbon nanotubes: perspective and issues. Chemical Communications, 45, 6886-4901.

[41] Ji, P., Tan, H., Xu, X., \& Feng, W. (2010). Lipase Covalently Attached to Multiwalled Carbon Nanotubes as an Efficient Catalyst in Organic Solvent. AIChE Journal, 56(11), 3005-3011.

[42] Upadhyayula, V., \& Gadhamshetty, V. (2010). Appreciating the role of carbon nanotube composites in preventing biofouling and promoting biofilms on material surfaces in environmental engineering: A review. Biotechnological Advances, 28(6), 802-816.

[43] Lojou, E., Luciano, P., Nitsche, S., \& Bianco, P. (1999). Poly(ester-sulfonic acid):modified carbon electrodes for the electrochemical study of c-type cytochromes. Electrochimica Acta, 44(19), 3341-3352.

[44] Lojou, E., Luo, X., Brugna, M., Candoni, N., Dementin, S., \& Giudici-Orticoni, M. T. (2008). Biocatalysts for fuel cells: efficient hydrogenase orientation for $\mathrm{H}_{2}$ oxidation at electrodes modified with carbon nanotubes. Journal of Biological Inorganic Chemistry, 13(7), 1157-1167.

[45] Minteer, S., Atanassov, P., Luckarift, H., \& Johnson, G. (2012). New materials for biological fuel cells. Material Today, 15(4), 166-173. 
[46] Weigel, M., Tritscher, E., \& Lisdat, F. (2007). Direct electrochemical conversion of bilirubin oxidase at carbon nanotube-modified glassy carbon electrodes. Electrochemistry Communications, 9(4), 689-693.

[47] Pumera, M., \& Smid, B. (2007). Redox protein noncovalent functionalization of double-wall carbon nanotubes: Electrochemical binder-less glucose biosensor. Journal of Nanosciences and Nanotechnology, 7(10), 3590-3595.

[48] Willner, I., Yan, Y. M., Willner, B., \& Tel-Vered, R. (2009). Integrated Enzyme-Based Biofuel Cells-A Review. Fuel Cells, 09(1), 7-24.

[49] Ueda, A., Kato, D., Kurita, R., Kamata, T., Inokuchi, H., Umemura, S., Hirono, S., \& Niwa, O. (2011). Efficient Direct Electron Transfer with Enzyme on a Nanostructured Carbon Film Fabricated with a Maskless Top-Down UV/Ozone Process. Journal of the American Chemical Society, 133(13), 4840-4846.

[50] Tasca, F., Gorton, L., Harreither, W., Haltrich, D., Ludwig, R., \& Nöll, G. (2088). Direct electron transfer at cellobiose dehydrogenase modified anodes for biofuel cells. Journal of Physical Chemistry C, 112(26), 9956-9961.

[51] Zheng, W., Zhao, H., Zhou, H., Xu, X., Ding, M., \& Zheng, Y. (2010). Electrochemistry of bilirubin oxidase at carbon nanotubes. Journal of Solid State Electrochemistry, 14(2), 249-254.

[52] Zheng, W., Zhou, H., Zheng, Y., \& Wang, N. (2008). A comparative study on electrochemistry of laccase at two kinds of carbon nanotubes and its application for biofuel cell. Chemical Physics Letters, 381-385.

[53] Zhao, L., Liu, H., \& Hu, N. (2006). Assembly of layer-by-layer films of heme proteins and single-walled carbon nanotubes: electrochemistry and electrocatalysis. Analytical Bioanalytical Chemistry, 384(2), 414-422.

[54] Liu, G., \& Lin, Y. (2006). Amperometric glucose biosensor based on self-assembling glucose oxidase on carbon nanotubes. Electrochemistry Communications, 8(2), 251-256.

[55] Iost, R., \& Crespilho, F. (2012). Layer-by-layer self-assembly and electrochemistry: Applications in biosensing and bioelectronics. Biosensors Bioelectronics, 31(1), 1-10.

[56] Gooding, J., Wibowo, R., Liu, J., Yang, W., Losic, D., Orbons, S., Mearns, F., Shapter, J., \& Hibbert, D. (2003). Protein electrochemistry using aligned carbon nanotube arrays. Journal of the American Chemical Society, 125(30), 9006-9007.

[57] Yu, X., Chattopadhyay, D., Galeska, I., Papadimitrakopoulos, F., \& Rusling, J. (2003). Peroxidase activity of enzymes bound to the ends of single-wall carbon nanotube forest electrodes. Electrochemistry Communications, 5(5), 408-411.

[58] Esplandiu, M., Pacios, M., Cyganek, L., Bartroli, J., \& Del Valle, M. (2009). Enhancing the electrochemical response of myoglobin with carbon nanotube electrodes. Nanotechnology. 
[59] Santhosh, P., Gopalan, A., \& Lee, K. (2006). Gold nanoparticles dispersed polyaniline grafted multiwall carbon nanotubes as newer electrocatalysts: Preparation and performances for methanol oxidation. Journal of Catalysis, 238(1), 177-185.

[60] Nazaruk, E., Karaskiewicz, M., Zelechowska, K., Biernat, J., Rogalski, J., \& Bilewicz, R. (2012). Powerful connection of laccase and carbon nanotubes Material for mediator-free electron transport on the enzymatic cathode of the biobattery. Electrochemistry Communications, 14(1), 67-70.

[61] Sadowska, K., Stolarczyk, K., Biernat, J., Roberts, K., Rogalski, J., \& Bilewicz, R. (2010). Derivatization of single-walled carbon nanotubes with redox mediator for biocatalytic oxygen electrodes. Bioelectrochemistry, 80(1), 73-80.

[62] Jeykumari, D., \& Narayanan, S. (2008). Fabrication of bienzyme nanobiocomposite electrode using functionalized carbon nanotubes for biosensing applications. Biosensors Bioelectronics, 23(11), 1686-1693.

[63] Wang, Z., Li, M., Su, P., Zhang, Y., Shen, Y., Han, D., Ivaska, A., \& Niu, L. (2008). Direct electron transfer of horseradish peroxidase and its electrocatalysis based on carbon nanotube/thionine/gold composites. Electrochemistry Communications, 10(2), 306-310.

[64] Le Floch, F., Thuaire, A., Bidan, G., \& Simonato, J. P. (2009). The electrochemical signature of functionalized single-walled carbon nanotubes bearing electroactive groups. Nanotechnology, 20(14), 45705.

[65] Alonso-Lomillo, M., Rüdiger, O., Maroto-Valiente, A., Velez, M., Rodriguez-Ramos, I., Munoz, F., Fernandez, V., \& De Lacey, A. (2007). Hydrogenase-coated carbon nanotubes for efficient $\mathrm{H}_{2}$ oxidation. Nano Letters, 7(6), 1603-1608.

[66] Jönsson-Niedziolka, M., Kaminska, A., \& Opallo, M. (2010). Pyrene-functionalised single-walled carbon nanotubes for mediatorless dioxygen bioelectrocatalysis. Electrochimica Acta, 55(28), 8744-8750.

[67] Karachevtsev, V., Stepanian, S., Glamazda, A., Karachevtsev, M., Eremenko, V., Lytvyn, O., \& Adamowicz, L. (2011). Noncovalent Interaction of Single-Walled Carbon Nanotubes with 1-Pyrenebutanoic Acid Succinimide Ester and Glucose oxidase. Journal of Physical Chemistry C, 115(43), 21072-21082.

[68] Lau, C, Adkins, E, Ramasamy, R, Lackarift, H, Johnson, G, \& Atanassov, P. (2012). Design of Carbon Nanotube-Based Gas-Diffusion Cathode for $\mathrm{O}_{2}$ Reduction by Multicopper Oxidases. Advanced Energy Materials, 2(1), 162-168.

[69] Xu, H., Xiong-Y, H., Zeng-X, Q., Jia, L., Wang, Y., \& Wang-F, S. (2009). Direct electrochemistry and electrocatalysis of heme proteins immobilized in single-wall carbon nanotubes-surfactant films in room temperature ionic liquids. Electrochemistry Communications, 11(2), 286-289.

[70] Yan, Y., Zheng, W., Zhang, M., Wang, L., Su, L., \& Mao, L. (2005). Bioelectrochemically functional nanohybrids through co-assembling of proteins and surfactants onto 
carbon nanotubes: Facilitated electron transfer of assembled proteins with enhanced faradic response. Langmuir, 21(14), 65606566.

[71] Cosnier, S., Ionescu, R., \& Holzinger, M. (2008). Aqueous dispersions of SWCNTs using pyrrolic surfactants for the electro-generation of homogeneous nanotube composites. Application to the design of an amperometric biosensor. Journal of Materials Chemistry, 18(42), 5129-5133.

[72] Gao, M., Dai, L., \& Wallace, G. (2003). Biosensors based on aligned carbon nanotubes coated with inherently conducting polymers. Electroanalysis, 15(13), 1089-1094.

[73] Tsai, C. Y., Li, C. S., \& Liao, W. S. (2006). Electrodeposition of polypyrrole-multiwalled carbon nanotube-glucose oxidase nanobiocomposite film for the detection of glucose. Biosensors Bioelectronics, 22(4), 495-500.

[74] Chen, H, \& Dong, S. (2007). Direct electrochemistry and electrocatalysis of horseradish peroxidase immobilized in sol-gel-derived ceramic-carbon nanotube nanocomposite film. Biosensors Bioelectronics, 22(8), 1811-1815.

[75] Heller, A. (2006). Electron-conducting redox hydrogels: design, characteristics and synthesis. Current Opinion in Chemical Biology, 10(6), 664-672.

[76] Timur, S, Anik, U, Odaci, D, \& Gorton, L. (2007). Development of a microbial biosensor based on carbon nanotube (CNT) modified electrodes. Electrochemistry Communications, 9(7), 1810-1815.

[77] Song, J., Shin, H., \& Kang, C. (2011). A Carbon Nanotube Layered Electrode for the Construction of the Wired Bilirubin Oxidase Oxygen Cathode. Electroanalysis, 23(12), 2941-2948.

[78] Tiwari, I., \& Singh, M. (2011). Preparation and characterization of methylene blueSDS- multiwalled carbon nanotubes nanocomposite for the detection of hydrogen peroxide. Microchimica Acta, 174(3-4), 223-230.

[79] Pakapongpan, S., Palangsuntikul, R., \& Surareungchai, W. (2011). Electrochemical sensors for hemoglobin and myoglobin detection based on methylene blue-multiwalled carbon nanotubes nanohybrid-modified glassy carbon electrode. Electrochimica Acta, 56(19), 6831-6836.

[80] Hoshino, T., Sekiguchi, S., \& Muguruma, H. (2012). Amperometric biosensor based on multilayer containing carbon nanotube, plasma-polymerized film, electron transfer mediator phenothiazine, and glucose dehydrogenase. Bioelectrochemistry, 84-1.

[81] Ciaccafava, A., Infossi, P., Giudici-Orticoni, M. T., \& Lojou, E. (2010). Stabilization role of a phenothiazine derivative on the electrocatalytic oxidation of hydrogen via Aquifex aeolicus hydrogenase at graphite membrane electrodes. Langmuir, 26(23), 18534-18541. 
[82] Tanne, C., Göbel, G., \& Lisdat, F. (2010). Development of a (PQQ)-GDH-anode based on MWCNT-modified gold and its application in a glucose $/ \mathrm{O}_{2}$-biofuel cell. Biosensors Bioelectronics, 26(2), 530-535.

[83] Reisner, E. (2011). Solar Hydrogen Evolution with Hydrogenases: From Natural to Hybrid Systems European. Journal of Inorganic Chemistry [7], 1005-1016.

[84] Vignais, P., \& Billoud, B. (2007). Occurrence, classification, and biological function of hydrogenases: An overview. Chemical Reviews, 107(10), 4206-4272.

[85] Parkin, A., Cavazza, C., Fontecilla-Camp, J., \& Armstrong, F. (2006). Electrochemical investigations of the interconversions between catalytic and inhibited states of the [FeFe]-hydrogenase from Desulfovibrio desulfuricans. Journal of the American Chemical Society, 128(51), 16808-16815.

[86] Dementin, S., Belle, V., Bertrand, P., Guigliarelli, B., Adryanczyk-Perrier, G., De Lacey, A., Fernandez, V., Rousset, M., \& Léger, C. (2006). Changing the ligation of the distal [4Fe4S] cluster in NiFe hydrogenase impairs inter- and intramolecular electron transfers. Journal of the American Chemical Society, 128(15), 5209-5218.

[87] Krassen, H., Stripp, S., von, Abendroth. G., Ataka, K., Happe, T., \& Heberle, J. (2009). Immobilization of the [FeFe]-hydrogenase CrHydA1 on a gold electrode: Design of a catalytic surface for the production of molecular hydrogen. Journal of Biotechnology, 142(1), 3-9.

[88] Zadvornyy, O., Lucon, J., Gerlach, R., Zorin, N., Douglas, T., Elgren, T., \& Peters, J. (2012). Photo-induced $\mathrm{H}_{2}$ production by [NiFe]-hydrogenase from T. roseopersicina covalently linked to a $\mathrm{Ru}(\mathrm{II})$ photosensitizer. Journal of Inorganic Biochemistry, 106(1), 151-155.

[89] Reisner, E., Powell, D., Cavazza, C., Fontecilla-Camps, J., \& Armstrong, F. (2009). Visible Light-Driven $\mathrm{H}_{2}$ Production by Hydrogenases Attached to Dye-Sensitized $\mathrm{TiO}_{2}$ Nanoparticles. J. Am. Chem. Soc., 131(51), 18457-18466.

[90] Morra, S., Valetti, F., Sadeghi, S., King, P., Meyer, T., \& Gilardi, G. (2011). Direct electrochemistry of an [FeFe]-hydrogenase on a $\mathrm{TiO}_{2}$ Electrode. Chemical Communications, 47(38), 10566-10568.

[91] Brown, K., Wilker, M., Boehm, M., Dukovic, G., \& King, P. (2012). Characterization of Photochemical Processes for $\mathrm{H}_{2}$ Production by CdS Nanorod-[FeFe] Hydrogenase Complexes. Journal of the American Chemical Society, 143(12), 5627-5636.

[92] Brown, K., Dayal, S., Ai, X., Rumbles, G., \& King, P. (2010). Controlled Assembly of Hydrogenase-CdTe Nanocrystal Hybrids for Solar Hydrogen Production. Journal of the American Chemical Society, 132(28), 9672-9680.

[93] Mc Donald, T., Svedruzic, D., Kim-H, Y., Blackburn, J., Zhang, S., King, P., \& Heben, M. (2007). Wiring-up hydrogenase with single-walled carbon nanotubes. Nano Letters, 7(11), 3528-3534. 
[94] Blackburn, J., Svedruzic, D., Mc Donald, T., Kim-H, Y., King, P., \& Heben, M. (2008). Raman spectroscoipy of charge transfer interaction between single wall carbon nanotubes and [FeFe] hydrogenase. Dalton Transactions, 5454-5461.

[95] Kihara, T., Liu-Y, X., Nakamura, C., Park-M, K., Yasuda-W, S., Qian-J, D., Kawasaki, K., Zorin, N., Yasuda, S., Hata, K., Wakayama, T., \& Miyake, J. (2001). Direct electron transfer to hydrogenase for catalytic hydrogen production using a single-walled carbon nanotubes forest. International Journal of Hydrogen Energy, 36(13), 7523-7529.

[96] Noda, K., Zorin, N., Nakamura, C., Miyake, M., Gogotov, I., Asada, Y., Akutsu, H., \& Miyake, J. (1998). Langmuir-Blodgett film of hydrogenase for electrochemical hydrogen production. Thin Solid Films, 327-329, 639-642.

[97] Elgren, T, Zadvorny, O, Brecht, E, Douglas, T, Zorin, N, Maroney, M, \& Peters, J. (2005). Immobilization of active hydrogenases by encapsulation in polymeric porous gels. Nano Letters, 5(10), 2085-2087.

[98] Zadvorny, O., Barrows, A., Zorin, N., Peters, J., \& Elgren, T. (2010). High level oh hydrogen production activity achieved for hydrogenase encapsulated in sol-gel material doped with carbon nanotubes. Journal of Materials Chemistry, 20-1065.

[99] Fontecave, M., \& Artero, V. (2011). Bioinspired catalysis at the crossroads between biology and chemistry: A remarkable example of an electrocatalytic material mimicking hydrogenases. Compte Rendu Chimie, 14(4), 362-371.

[100] Dubois, M., \& Dubois, D. (2009). The roles of the first and second coordination spheres in the design of molecular catalysts for $\mathrm{H}_{2}$ production and oxidation. Chemical Society Reviews, 38(1), 62-72.

[101] Le Goff, A., Artero, V., Jousselme, B., Tran, P. D., Guillet, N., Metaye, R., Fihri, A., Palacin, S., \& Fontecave, M. (2009). From Hydrogenases to Noble Metal-Free Catalytic Nanomaterials for $\mathrm{H}_{2}$ Production and Uptake. Science, 326(5958), 1384-1387.

[102] Yahiro, A., Lee, S., \& Kimble, D. (1964). Bioelectrochemistry I. Enzyme utilizing Biofuel cell studies. Biochimica Biophysica Acta, 88, 375-383.

[103] Franks, Ashley. E., \& Nevin, Kelly. P. (2010). Microbial Fuel Cells. A Current Review. Energies, 3(5), 899-919.

[104] Zhou, M., Chi, M., Luo, J., He, H., \& Jin, T. (2011). An overview of electrode materials in microbial fuel cells. Journal of Power Sources, 196(10), 4427-4435.

[105] Sokic-Lazic, D., \& Minteer, S. (2008). Citric acid cycle biomimic on a carbon electrode. Biosensors Bioelectronics, 24(4), 939-944.

[106] Egorova, K., \& Antranikian, G. (2005). Industrial relevance of thermophilic Archaea. Current Opinion in Microbiology, 8(6), 649-655.

[107] Halamkova, L., Halamek, J., Bocharova, V., Szczupak, A., Alfonta, L., \& Katz, E. (2012). Implanted Biofuel Cell Operating in a Living Snail. Journal of the American Chemical Society, 134(11), 5040-5043. 
[108] Cinquin, P., Gondran, C., Giroud, F., Mazabrard, S., Pellissier, A., Boucher, F., Alcaraz, J. P., Gorgy, K., Lenouvel, F., Mathé, S., Porcu, P., \& Cosnier, S. (2010). A Glucose BioFuel Cell Implanted in Rats. PLoS ONE, 5, e10476.

[109] Falk, M., Andoralov, V., Blum, Z., Sotres, J., Suyatin, D., Ruzgas, T., Arnebrant, T., \& Shleev, S. (2012). Biofuel cell as a power source for electronic contact lenses. Biosensors Bioelectronics, 37(1), 38-45.

[110] Zebda, A., Gondran, C., Le Goff, A., Holzinger, M., Cinquin, P., \& Cosnier, S. (2011). Mediatorless high-power glucose biofuel cells based on compressed carbon nanotube-enzyme electrodes. Nature Com., 2-370.

[111] Zhao, H., Zhou, H., Zhang, J., Zheng, W., \& Zheng, Y. (2009). Carbon nanotube-hydroxyapatite nanocomposite: A novel platform for glucose $/ \mathrm{O}_{2}$ biofuel cell. Biosensors Bioelectronics, 25(2), 463-468.

[112] Liu, J., Zhang, X., Pang, H., Liu, B., Zou, Q., \& Chen, J. (2012). High-performance bioanode based on the composite of CNTs-immobilized mediator and silk film-immobilized glucose oxidase for glucose $/ \mathrm{O}_{2}$ biofuel cells. Biosensors Bioelectronics, 31(1), 170-175.

[113] Gao, F., Yan, Y., Su, L., Wang, L., \& Mao, L. (2007). An enzymatic glucose/O ${ }_{2}$ biofuel cell: Preparation, characterization and performance in serum. Electrochemistry Communications, 9(5), 989-996.

[114] Li, X., Zhou, H., Yu, P., Su, L., Ohsaka, T., \& Mao, L. (2008). A miniature glucose/O $\mathrm{O}_{2}$ biofuel cell with single-walled carbon nanotubes-modified carbon fiber microelectrodes as the substrate. Electrochemistry Communications, 10(6), 851-854.

[115] Nazaruk, E., Sadowska, K., Biernat, J., Rogalski, J., Ginalska, G., \& Bilewicz, R. (2010). Enzymatic electrodes nanostructured with functionalized carbon nanotubes for biofuel cell applications. Analytical and Bioanalytical Chemistry, 398(4), 1651-1660.

[116] Lim, J., Malati, P., Bonet, F., \& Dunn, B. (2007). Nanostructured sol-gel electrodes for biofuel cells. Journal of the Electrochemical Society, 154(2), A140-A145.

[117] Karaskiewicz, M., Nazaruk, E., Zelzchowska, K., Biernat, J., Rogalski, J., \& Bilewicz, R. (2012). Fully enzymatic mediatorless fuel cell with efficient naphthylated carbon nanotube-laccase composite cathodes. Electrochemistry Communications, 20-124.

[118] Tasca, F., Gorton, L., Harreither, W., Haltrich, D., Ludwig, R., \& Nöll, G. (2008). Highly efficient and versatile anodes for biofuel cells based on cellobiose dehydrogenase from Myriococcum thermophilum. Journal of Physical Chemistry C, 112(35), 13668-13673.

[119] Wang, Y., \& Yao, Y. (2012). Direct electron transfer of glucose oxidase promoted by carbon nanotubes is without value in certain mediator-free applications. Microchimica Acta, 176(3-4), 271-277. 
[120] Vincent, K., Parkin, A., \& Armstrong, F. (2007). Investigating and exploiting the electrocatalytic properties of hydrogenases. Chemical Reviews, 107(10), 4366-4413.

[121] Liebgott, P. P., de Lacey, A., Burlat, B., Cournac, L., Richaud, P., Brugna, M., Fernandez, V., Guigliarelli, B., Rousset, M., Léger, C., \& Dementin, S. (2011). Original Design of an Oxygen-Tolerant [NiFe] Hydrogenase: Major Effect of a Valine-to-Cysteine Mutation near the Active Site. Journal of the American Chemical Society, 133(4), 986-997.

[122] Cracknell, J. A., Vincent, K. A., Ludwig, M., Lenz, O., Friedrich, B., \& Armstrong, F. A. (2008). Enzymatic Oxidation of $\mathrm{H}_{2}$ in Atmospheric $\mathrm{O}_{2}$ : The Electrochemistry of Energy Generation from Trace $\mathrm{H}_{2}$ by Aerobic Microorganisms. Journal of the American Chemical Society, 130(2), 424-425.

[123] Luo, X. J., Brugna, M., Infossi, P., Giudici-Orticoni, M. T., \& Lojou, E. (2009). Immobilization of the hyperthermophilic hydrogenase from Aquifex aeolicus bacterium onto gold and carbon nanotube electrodes for efficient $\mathrm{H}_{2}$ oxidation. Journal of Biological Inorganic Chemistry, 14(8), 1275-1288.

[124] Svedruzic, D., Blackburn, J., Tenent, R., Rocha, D. J., Vinzant, T., Heben, M., \& King, P. (2011). High-performance hydrogen production and oxidation electrodes with hydrogenase supported on metallic single-wall carbon nanotubes networks. Journal of the American Chemical Society, 133(12), 4299-4306.

[125] Sun, Q., Zorin, N. A., Chen, D., Chen, M., Liu, X. T., Miyake, J., \& Qian, J. D. (2010). Langmuir-Blodgett films of pyridyldithio-modified multiwalled carbon nanotubes as a support to immobilize hydrogenase. Langmuir, 26(12), 10259-10265.

[126] Hoeben, F. J. M., Heller, I., Albracht, S. P. J., Dekker, C., Lemay, S. G., \& Heering, H. A. (2008). Polymyxin-coated Au and Carbon nanotubes electrodes for stable [NiFe]hydrogenase film voltammetry. Langmuir, 24(11), 5925-5931.

[127] Baur, J., Le Goff, A., Dementin, S., Holzinger, M., Rousset, M., \& Cosnier, S. (2011). Three-dimensional carbon nanotube-polypyrrole-[NiFe] hydrogenase electrodes for the efficient electrocatalytic oxidation of $\mathrm{H}_{2}$. International Journal of Hydrogen Energy, 36(19), 12096-12101.

[128] Ciaccafava, A., Infossi, P., Ilbert, M., Guiral, M., Lecomte, S., Giudici-Orticoni, M. T., \& Lojou, E. (2012). Electrochemistry, AFM, and PM-IRRA Spectroscopy of Immobilized Hydrogenase: Role of a Hydrophobic Helix in Enzyme Orientation for Efficient $\mathrm{H}_{2}$ Oxidation. Angewandte Chemistry International Edition, 51(4), 953-956.

[129] Volbeda, A., Amara, P., Darnault, C., Mouesca, J. M., Parkin, A., Roessler, M. M., Armstrong, F. A., \& Fontecilla-Camps, J. C. (2012 ). X-ray crystallographic and computational studies of the $\mathrm{O}_{2}$-tolerant $[\mathrm{NiFe}]$-hydrogenase 1 from Escherichia coli. Proceeding of the National Academic Sciences, 10(14), 5305-5310.

[130] Shomura, Y., Yoon, S. K., Nishihara, H., \& Higuchi, Y. (2011). Structural basis for a [4Fe-3S] cluster in the oxygen-tolerant membrane-bound [NiFe]-hydrogenase. Nature NIL_143., 479(7372), 253. 
[131] Pandelia, M., Fourmond, V., Tron, P., Lojou, E., Bertrand, P., Léger, C., Giudici-Orticoni, M. T., \& Lubitz, W. (2010). Membrane-Bound Hydrogenase I from the Hyperthermophilic Bacterium Aquifex aeolicus: Enzyme Activation, Redox Intermediates and Oxygen Tolerance. Journal of the American Chemical Society, 132(20), 6991-7004.

[132] Fritsch, J., Scheerer, P., Frielingsdorf, S., Kroschinsky, S., Friedrich, B., Lenz, O., \& Spahn, C. M. T. (2011). The crystal structure of an oxygen-tolerant hydrogenase uncovers a novel iron-sulphur centre. Nature NIL_134., 479(7372), 249.

[133] Krishnan, S., \& Armstrong, F. A. (2012). Order-of-magnitude enhancement of an enzymatic hydrogen-air fuel cell based on pyrenyl carbon nanostructures. Chemical Science, 3(4), 1015-1023.

[134] Vincent, K., Cracknell, J., Clark, J., Ludwig, M., Lenz, O., Friedrich, B., \& Armstrong, F. (2006). Electricity from low-level $\mathrm{H}_{2}$ in still air- an ultimate test for an oxygen tolerant hydrogenase. Chemistry Communications, 5033-5035.

[135] Wait, A., Parkin, A., Morley, G., dos, Santos. L., \& Armstrong, F. (2010). Characteristics of enzyme-based hydrogen fuel cells using an oxygen-tolerant hydrogenase as the anodic catalyst. Journal of Physical Chemistry C, 114(27), 12003-12009.

[136] Ciaccafava, A., de Poulpiquet, A., Techer, V., Giudici-Orticoni, M. T., Tingry, S., Innocent, C., \& Lojou, E. (2012). An innovative powerful and mediatorless $\mathrm{H}_{2} / \mathrm{O}_{2}$ biofuel cell based on an outstanding bioanode. Electrochemistry Communications, 23, 25-28.

[137] Infossi, P., Lojou, E., Chauvin, J. P., Herbette, G., Brugna, M., \& Giudici-Orticoni, M. T. (2010). Aquifex aeolicus membrane hydrogenase for hydrogen bioxidation: role of lipids and physiological partners in enzyme stability and activity. International Journal of Hydrogen Energy, 35(19), 10778-10789.

[138] Reuillard, B., Le Goff, A., Agnès, A., Zebda, A., Holzinger, M., \& Cosnier, S. (2012). Direct electron transfer between tyrosinase and multi-walled carbon nanotubes for bioelectrocatalytic oxygen reduction. Electrochemistry Communications, 20, 19-22.

[139] Durand, F., Kjaergaard, C., Suraniti, E., Gounel, S., Hadt, R., \& Solomon, E. (2012). Mano N Bilirubin oxidase from Bacillus pumilus: A promising enzyme for the elaboration of efficient cathodes in biofuel cells. Biosensors Bioelectronics, 35(1), 140-146. 